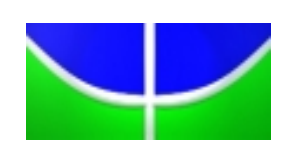

Universidade de Brasília

Centro de Excelência em Turismo

\title{
TURISMO, ESPAÇO E EDUCAÇÃO EM BRASÍLIA: UMA VISÃO DO TURISMO ENTRE PROFISSIONAIS DA EDUCAÇÃO NO DISTRITO FEDERAL
}

\author{
WANDERLEY GOMES DE CARVALHO
}

RAFAEL SANZIO ARAÚJO DOS ANJOS

(orientador)



Brasília, DF

Dezembro de 2003 


\title{
UNIVERSIDADE DE BRASÍLIA \\ Centro de Excelência em Turismo \\ Curso de Especialização em TURISMO E \\ HOSPITALIDADE
}

\author{
TURISMO, ESPAÇO E EDUCAÇÃO EM BRASÍLIA: \\ UMA VISÃO DO TURISMO ENTRE PROFISSIONAIS DA \\ EDUCAÇÃO NO DISTRITO FEDERAL
}

WANDERLEY GOMES DE CARVALHO

Banca Examinadora:

Prof. Dr. Rafael Sanzio Araújo dos Anjos
Orientador

Membro da Banca

Brasília, DF

Dezembro de 2003 
c331t CARVALHO, Wanderley Gomes de

Turismo, Espaço e Educação em Brasília: uma visão do Turismo entre Profissionais de Educação no

Distrito Federal/ Wanderley Gomes de Carvalho.

Monografia (especialização) - Universidade de Brasília.

Centro de Excelência em Turismo. Brasília, 2003.

58p.

Área de concentração: Turismo

Orientador: Rafael Sanzio Araújo dos Anjos.

CDU 338.482.2

1. Turismo 2. Educação 


\section{WANDERLEY GOMES DE CARVALHO}

TURISMO, ESPAÇO E EDUCAÇÃO EM BRASÍLIA: UMA VISÃO DO TURISMO ENTRE PROFISSIONAIS DA EDUCAÇÃO NO DISTRITO FEDERAL

Comissão Avaliadora

Professor(a) Orientador(a)

Brasília, DF

Dezembro de 2003 
DEDICATÓRIA

À Ana Paula, minha esposa, e meus filhos Alyne, Ayane, Yagho e Yohann. 


\section{AGRADECIMENTOS}

À minha esposa, pela compreensão e apoio nos momentos de dificuldade.

Aos meus filhos, Alyne, Ayane, Yagho e Yohann pela compreensão, carinho e respeito que sempre me dedicaram.

Aos meus colegas de classe, em especial a Gilberto e José Barbosa que desde o começo do curso senviram de modelo de perseverança e dedicação ao trabalho.

Ao professor Rafael Sanzio, pela orientação do trabalho, sempre de forma sensata e precisa.

À coordenação do Curso, especialmente à professora Tânia Montoro, pela garra, rigidez e temura que dedicou a esta causa.

Aos professores, que contribuíram em cada momento do curso e no trabalho final.

Agradeço, enfim, a todos aqueles que direta ou indiretamente contribuíram para que este trabalho fosse concluído. 


\section{EPÍGRAFE}

“Se, de um lado, não posso me adaptar ou me 'converter' ao saber ingênuo dos grupos populares, de outro, não posso, se realmente progressista, impor-lhes arrogantemente o meu saber como verdadeiro. $O$ dialogo em que se vai desafiando o grupo popular a pensar sua historia social como a experiência igualmente social de seus membros, vai revelando a necessidade de superar certos saberes que, desnudos, vão mostrando sua 'incompetência' para explicar os fatos."

Paulo Freire 


\section{RESUMO}

Este trabalho tem como principal objetivo analisar a forma como o ensino público do Distrito Federal pode colaborar com a cidade no sentido de desenvolver uma cultura turística, valorizando o plano piloto e demais cidades, tanto no aspecto arquitetônico, como na valorização da memória.

No primeiro capítulo apresentamos algumas noções básicas de turismo e como este conhecimento pode estar associado à educação pública, no sentido de integrar a população local e oferecer alternativas viáveis para a visitação da cidade.

O segundo capítulo está dividido em 3 partes: políticas públicas para o turismo no Distrito Federal (como os diversos órgãos governamentais tratam da política para o turismo e como esta pode estar associada à educação em geral), o turismo e o ensino no Distrito Federal (como os professores das escolas públicas entendem os conceitos de turismo, como eles aplicam estes conhecimentos em sala de aula, as dificuldades e potencialidades da educação como auxiliar do turismo na cidade) e, por fim, o turismo, a representação espacial e a educação (como as três áreas podem se integrar e promover a cidade de forma mais adequada para o turismo).

No último capítulo fazemos as considerações finais, com dois subitens, as conclusões e as recomendações.

Como conclusões temos:

1. A população tem dificuldade de conhecer a cidade de forma mais completa, pela baixa escolaridade;

2. A violência incomoda, além da população local, também o turista;

3. Há uma certa dificuldade de encontrar mapas turísticos da cidade;

4. O governo oferece poucos incentivos à população quanto à participação no turismo local;

5. Os professores têm dificuldades para buscar uma bibliografia atualizada acerca do turismo e da cidade.

Fazemos as seguintes recomendações: 
1. Que possam ser colocados mapas da cidade nos locais de maior concentração turística;

2. Que o governo e os diversos órgãos de turismo e cultura possam incentivar maior visitação de alunos das escolas pública a museus e demais locais turísticos da cidade;

3. Que o governo trabalhe a questão da segurança pública de forma mais eficaz, de modo a criar na população a sensação de segurança e liberdade;

4. Que as escolas possam ser equipadas com livros atualizados para consultas de professores e alunos nas bibliotecas;

5. Que a população possa acreditar na cidade como um portal de entrada para o turismo no Brasil.

PALAVRAS CHAVES: Turismo, Educação. 


\section{ABSTRACT}

This work has as main objective to analyze the form as the public education of the DF can collaborate with the city in the direction to develop a tourist culture, valuing the Plain Pilot and too much cities, as much in the aspect architectural, as in the valuation of the memory, etc.

In the first chapter we present some basic slight knowledge of tourism and as this knowledge can be associated the public education, in the direction to integrate the local population and to offer viable alternatives for the visitation of the city.

The second chapter is divided in 3 parts: public politics for the tourism in the DF (as the diverse governmental bodies they deal with the politics for the tourism and as this can be associated to the education in general), the tourism and education in the DF (how the teachers of the public schools of the DF they understand the tourism concepts, how they apply these knowledge in classroom, the difficulties and potentialities of the education as to assist of the tourism in city) and, finally, the tourism, the space representation and the education (how the three areas they can if integrate and promote the city to adequate form for the tourism).

In the last chapter we make the final considerations, with two subitems, the conclusions and the recommendations.

As conclusions we have:

1. The population has difficulty to know the city of more complete form by low the scholarly;

2. The violence bothers, beyond the local population, also the tourist;

3. It has a certain difficulty to find maps tourist of the city;

4. The government gives to few incentives to the population how much the participation in the local tourism;

5. The teachers have difficulties to search a bibliography brought up to date concerning the tourism and of the city.

We make the following recommendations: 
1. That maps of the city in the places of bigger tourist concentration can be placed;

2. That the government and the diverse agencies of tourism and culture can stimulate greater visitation of students of the schools public the tourist excessively local museums and of the city;

3. That the government works the question of the public security guard of more efficient form, in order to create in the population the sensation of security and freedom;

4. That the schools can be equipped with books brought up to date for consultations of teacher and students in libraries;

5. That the population can believe the city as a vestibule of entrance for the tourism in Brazil.

WORDS KEYS: Tourism, Education. 


\section{LISTA DE ABREVIATURAS}

\begin{tabular}{|c|c|}
\hline DF & DISTRITO FEDERAL \\
\hline EUA & ESTADOS UNIDOS DA AMÉRICA \\
\hline FIG. & FIGURA \\
\hline GDF & GOVERNO DO DISTRITO FEDERAL \\
\hline OMT & ORGANIZAÇÃO MUNDIAL DO TURISMO \\
\hline SCEN & SETOR DE CLUBES ESPORTIVOS NORTE \\
\hline SCLN & SETOR COMERCIAL LOCAL NORTE \\
\hline SDS & SETOR DE DIVERSÕES SUL \\
\hline SGAS & SETOR DE GRANDES ÁREAS SUL \\
\hline SHIS & SETOR DE HABITAÇAO ISOLADAS SUL \\
\hline SQS & SUPERQUADRA SUL \\
\hline SRTVS & SETOR DE RÁDIO E TELEVISÃO SUL \\
\hline TV & TELEVISÃO \\
\hline CEF & CENTRO DE ENSINO FUNDAMENTAL \\
\hline CEM & CENTRO DE ENSINO MÉDIO \\
\hline CENB & CENTRO DE ENSINO DO NÚCLEO BAND \\
\hline
\end{tabular}




\section{ÍNDICE DAS FIGURAS ${ }^{1}$}

FIG. 01 - FOTO DA CATEDRAL À NOITE

FIG. 02 - BALNEÁRIO CAMBURIÚ - ORLA MARÍTIMA 23

FIG. 03 - FOLDER CAMINHOS DO SOL

FIG. 04 - IMAGEM DE SATÉLITE DE BRASÍLIA - NASA 27

FIG. 05 - ESPLANADA VISTA POR TRÁS DO CONGRESSO $\mathbf{2 8}$

FIG. 06 - FOTO DE SIDNEY - AUSTRÁLIA

FIG. 07 - FOTO DE LONDRES - INGLATERRA 31

FIG. 08 - FOTO DE COLÚMBIA BRITÂNICA - CANADÁ 32

FIG. 09 - ESPLANADA VISTA DA TORRE DE TV 33

FIG. 10 - VISÃO EM PERSPECTIVA DE BRASÍLIA 39

FIG. 11 - IMAGEM DE SATÉLITE DE BRASÍLIA - INPE 40

FIG. 12 - MAPA DO DF $\quad \mathbf{4 0}$

FIG. 13 - CATETINHO

FIG. 14 - PONTE JK 43

FIG. 15 - MAPA RODOVIÁRIO DE BRASÍLIA 43

FIG. 16 - MAPA RODOVIÁRIO DO DF

FIG. 17 - PARQUE DO GAMA

FIG. 18 - PARQUE OLHOS D'ÁGUA 45

FIG. 19 - ESTAÇÃO ESPACIAL COM BRASÍLIA AO FUNDO 45

FIG. 20 - FOTO DE BRASÍLIA AO CAIR DA TARDE 46

1 As figuras $01,04,05,09,10,13,14,19$ e 20 foram retiradas do site: www.brasiliense.hpg.ig.com.br; as figuras 12,15 e 16 foram extraídas dos sites: www.prometeus.itsa.com.br e www.Viaecológica.com.br e a figura 02 foi copiada do site: www.secturbc.com.br. A figura 03 foi retirada da fonte: VELOSO, Marcelo Parreira, Turismo Simples e Eficiente. São Paulo, ed. Roca, 2003; as figuras 06, 07, 08 foram extraídas da fonte: HALL, C. Michael. Planejamento Turístico - Políticas, Processos e Relacionamentos. Ed. Contexto, São Paulo, 2001 e as figuras 17 e 18 partiram da seguinte fonte: CORREIO BRASILIENSE, Caderno Cidades, 21 de setembro de 2003. 


\section{SUMÁRIO}

$\begin{array}{ll}\text { INTRODUÇÃO } & 15\end{array}$

CAPITULO 1 - ALGUNS CONCEITOS DE TURISMO 17

1.1 - DEFINIÇÃO DE TURISMO - UMA SÍNTESE 18

1.2 - PROBLEMAS NO DESENVOLVIMENTO DO TURISMO 23

CAPITULO 2 - O TURISMO E EDUCAÇÃO 27

2.1 - POLÍTICA PARA O TURISMO NO DF 29

2.2 - O TURISMO E O ENSINO NO DF 33

2.3 - O USO DE MAPAS NO ENSINO E NO TURISMO 39

CAPÍTULO 3 - CONSIDERAÇÕES FINAIS 46

$\begin{array}{ll}\text { CONCLUSÕES } & 47\end{array}$

$\begin{array}{ll}\text { RECOMENDAÇÕES } & 49\end{array}$

$\begin{array}{ll}\text { ANEXO } & 51\end{array}$

REFERÊNCIAS BIBLIOGRÁFICAS 


\section{INTRODUÇÃO}

Este trabalho versa sobre como o turismo e a educação podem se complementar e alterar a espacialidade no Distrito Federal.

O Distrito Federal é uma área propícia para ser explorada turisticamente desde sua inauguração, mais precisamente, desde quando as pessoas vieram trabalhar atendendo ao chamado do Presidente Juscelino Kubitscheck de Oliveira, que, em 1957, iniciou a tarefa de construir uma nova capital do país no Planalto Central, já prevista na Constituição de 1891 e promessa eleitoral feita na cidade de Catalão - GO, em 1955.

Atribuímos a esta brava gente o início de uma nova realidade: a mudança da Capital do Brasil para o interior do país. À nossa população que vive hoje neste local, cabe-nos a oportunidade e a responsabilidade de fazer desta uma grande capital e um grande país.

O turismo pode alterar a realidade estampada, incentivando os brasileiros e estrangeiros a conhecer e entender que aqui temos atrativos para todos os gostos, desde um tour para conhecer a arquitetura da cidade, os esportes radicais, pelos ralis e passeios nas áreas rurais, até uma visão eclética e mística da religiosidade brasileira.

Este trabalho tem como principal objetivo analisar a forma como o ensino público do Distrito Federal pode colaborar com a cidade no sentido de desenvolver uma cultura turística, valorizando o plano piloto e demais cidades, tanto no aspecto arquitetônico, como na valorização da memória, etc.

O Trabalho está dividido em três capítulos, que serão mais bem detalhados a seguir.

No primeiro capitulo, falamos sobre algumas definições de Turismo, realizamos algumas considerações que pensamos ser de primordial importância, dentre as quais fazemos uma comparação entre os diversos conceitos existentes e da possibilidade real de ampliar seu entendimento. Falaremos ainda neste capítulo, dos problemas que são específicos do turismo no Distrito Federal, que, infelizmente, é comum em muitas outras localidades no Brasil e no mundo, como é a violência urbana e o descaso com a conservação da estrutura turística no DF. Tudo isso estabelecendo um elo entre a ciência turismo, o modo de fazer a pesquisa, com a educação fundamental e média, mostrando, 
principalmente que os conceitos ali expostos estão em consonância com a realidade e pode ser visualizada no dia-a-dia dos alunos, apresentando-se também sob a forma de oportunidade potencial de trabalho para a população de baixa renda. Neste caso, com os conhecimentos específicos de turismo podemos abrir novos horizontes para outras possibilidades de trabalho, renda, e inclusão social, temas tão discutidos no dias atuais.

No segundo capítulo trataremos a questão do turismo e a educação pública no Distrito Federal. No primeiro segmento, buscamos direcionar a questão de qual é a linha de pensamento dos governantes acerca dos caminhos adotados para desenvolver o turismo, tanto no Brasil, quanto no Distrito Federal, tomando por base os documentos produzidos para divulgação dos diversos órgãos vinculados ao turismo, entrevista, tanto de revistas com de outras mídias.

O segundo segmento trabalha o contexto do ensino do Turismo na Escola Pública, níveis fundamental e médio. Buscamos, através de contato informal com professores nas disciplinas de Geografia, história e de projetos especiais criados pelas escolas visitadas. Entre os dias 20 a 24 de outubro de 2003 foram visitadas escolas de diversas cidades satélites e de Brasília, com o objetivo de verificar a forma de colaboração dos professores ao mostrar a importância do turismo local e possibilidades de intervenção da população para melhorar a imagem da cidade e assim aumentar a visitação da mesma.

O terceiro segmento deste segundo capítulo tratamos dos mapas e o Turismo. É uma aplicação prática do que pode ser realizada em sala de aula, apresentando possibilidades dentro da Geografia, disciplina mais próxima que pode colaborar com o turismo em geral, onde, através de uma visão espacial do Distrito Federal, pode-se intervir qualitativamente no espaço.

Nas considerações finais, além de um resumo do que foi relatado no decorrer do trabalho, faremos algumas sugestões que podem ser realizadas de forma a melhor interagir o turismo na realidade da população do Distrito Federal, dirimindo as dificuldades e conscientizando a população para uma outra visão do DF. 


\section{CAPITULO 1}

\section{ALGUNS CONCEITOS DE TURISMO}

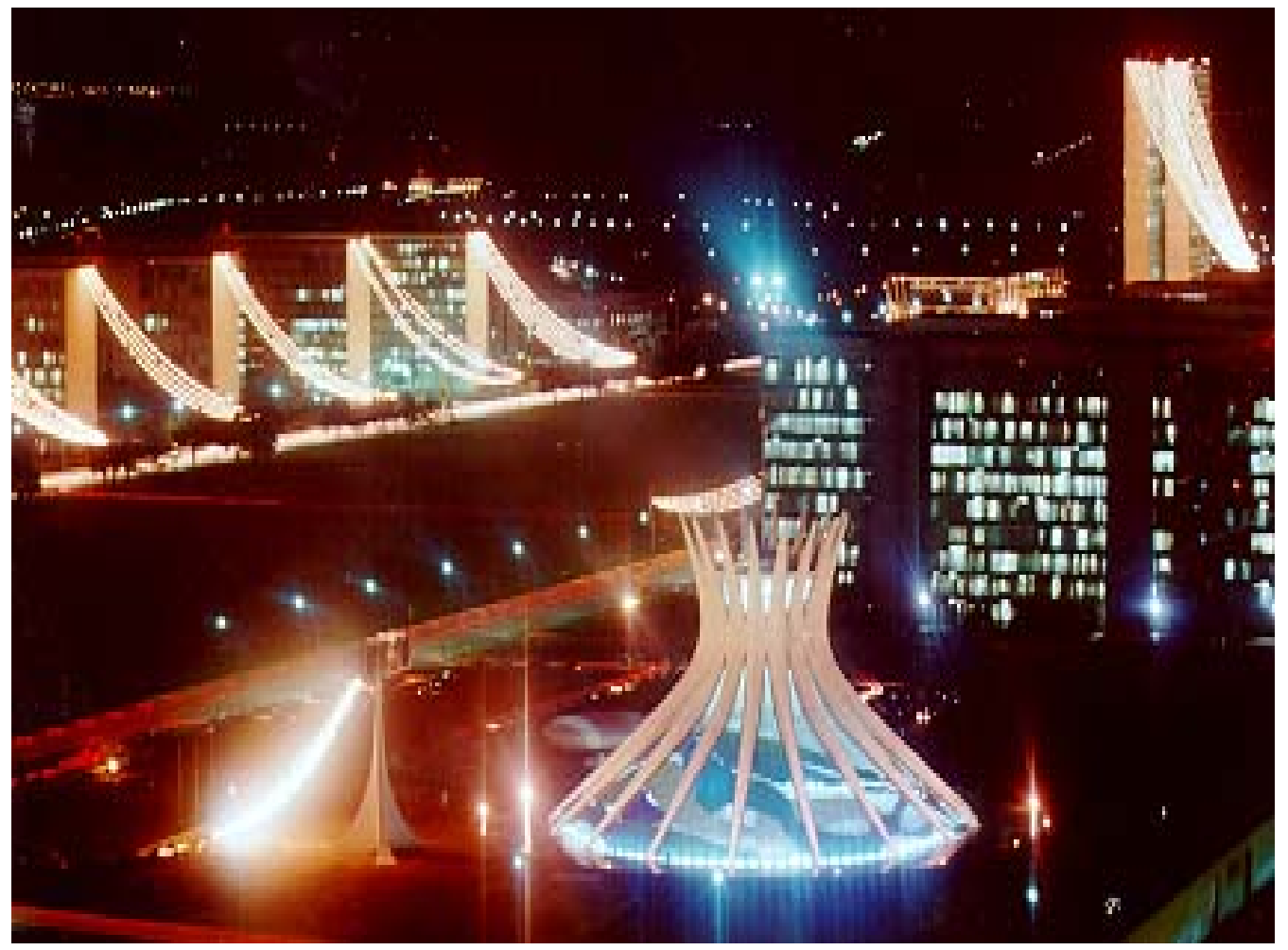

Fig.1 - Foto da Catedral de Brasília à noite

fonte: www.brasiliense.hpg.ig.com.br 
Neste primeiro capítulo apresentaremos alguns conceitos de turismo, além de uma discussão sobre questões intrínsecas a este setor da economia, tais como, aparelhos turísticos, o turista e os problemas enfrentados pelo setor nos últimos anos.

Faremos também uma comparação entre os diversos conceitos do turismo e apontando a possibilidade real de ampliar seu entendimento. Falaremos ainda neste capítulo dos problemas específicos do turismo no Distrito Federal, entre eles a violência urbana e o descaso com a conservação da estrutura urbanística no Distrito Federal.

\section{1 - DEFINIÇÃO DE TURISMO - UMA SÍNTESE}

O turismo não é um fenômeno novo, embora no Brasil seu estudo iniciou-se na década de 70, tomando um rumo mais intenso na segunda metade da década de 90.

No mundo, seu histórico remonta aos tempos do imperialismo, ainda no século XIX, quando a elite, por ter tempo disponível, dinheiro de sobra, facilidade para viajar e desejo de conhecer diferentes culturas. Na Europa e nos Estados Unidos surgiram os primeiros estabelecimentos com a preocupação de atrair visitantes, como Monte Carlo, com seus cassinos; a exploração dos Alpes suíços e a criação do parque Nacional de Yellowstone, nos EUA. Surgiram nesta mesma época os primeiros serviços para facilitar o acesso da população a estas instalações, tais como as agências de viagens.

Definir Turismo não é muito fácil, devido às várias abordagens e nuances que o termo pode tomar. Alguns autores relacionam turismo com viagens de qualquer espécie, mas pode ser considerado um começo adequado para uma abordagem da amplitude e dos limites deste conceito.

Conforme Trigo (2002) "turismo faz parte do universo maior denominado lazer. Entende-se por lazer as atividades desenvolvidas fora do sistema produtivo (trabalho), as obrigações sociais, religiosas e familiares"'?.

Já de acordo com a OMT (Organização Mundial do Turismo), turismo é: "o deslocamento para fora do local de residência por período superior a 24 horas e inferior a 60 dias motivado por razões não econômicas"3.

Outras definições do termo Turismo estão apresentadas a seguir:

\footnotetext{
${ }^{2}$ TRIGO, Luiz Gonzaga Godoi. Turismo Básico. 6ª ed. Ed. Senac, São Paulo, 2002.

${ }^{3}$ OMT in IGNARRA, Luiz Renato. Fundamentos do Turismo. Ed. Pioneira. São Paulo, 1999.
} 
- "O turismo é uma atividade humana intencional que serve como meio de comunicação e como elo de interação entre povos, tanto dentro como fora de um país. Envolve o deslocamento temporário de pessoas para outras regiões ou países visando à satisfação de outras necessidades que não a de atividades remuneradas" "'.".

- "É a soma de relações e de senviços resultantes de uma mudança de residência temporária e voluntária motivada por razões alheias a negócios ou profissionais ${ }^{\prime 4}$

- "É a soma das operações, especialmente de natureza econômica, diretamente relacionada com entrada, a permanência e o deslocamento de estrangeiros para dentro e para fora de um país, cidade ou região,5

- "O conjunto de viagens que tem por objetivo o prazer ou motivos comerciais, profissionais ou outros análogos, durante os quais é temporária sua ausência da residência habitual. As viagens realizadas para locomover-se ao local de trabalho não se constituem em turismo." ${ }^{\circ}$

- "O conjunto das inter-relações e dos fenômenos que se produzem como conseqüência das viagens e das estradas de forasteiros, sempre que delas não resulte um assentamento permanente nem que eles se vinculem a alguma atividade produtiva."

- "Turismo pode ser definido como a ciência, a arte de atrair e transportar visitantes, alojá-los e cortesmente satisfazer suas necessidades de desejos"8

- "É o estudo do homem longe de seu local de residência, da indústria que satisfaz suas necessidades, e dos impactos que ambos, ele e a indústria, geram sobre os ambiente físico, econômico e sócio-cultural da área receptora",

- "É o conjunto de senviços que tem por objetivo o planejamento, a promoção e a execução de viagens, e os serviços de recepção, hospedagem e atendimento aos indivíduos, e aos grupos, fora de suas residências habituais." ${ }^{110}$

Com as definições apresentadas acima, podemos tecer algumas considerações.

O Turismo é uma atividade econômica, uma vez que se baseia na exploração

${ }^{4}$ DE LA TORRE, Oscar Padilha. El Turismo- Fenômeno Social. In ANSARA, Marília Gomes dos Reis (org.) Turismo, como aprender, como ensinar. Ed. Senac, SP. $2^{\mathrm{a}}$ ed. 2001.

${ }^{5}$ SCHULLARD, Herman Von in IGNARRA, Luiz Renato. Fundamentos do Turismo. Ed. Pioneira. São Paulo, 1999.

${ }^{6}$ BORMANN, Arthur, in IGNARRA, Luiz Renato. Fundamentos do Turismo. Ed. Pioneira. São Paulo, 1999.

${ }^{7}$ HUNZIKER E KRAPF in IGNARRA, Luiz Renato. Fundamentos do Turismo. Ed. Pioneira. São Paulo, 1999.

${ }^{8}$ McINTOSH, Robert, in IGNARRA, Luiz Renato. Fundamentos do Turismo. Ed. Pioneira. São Paulo, 1999.

9 JAFARI, Jafar, in IGNARRA, Luiz Renato. Fundamentos do Turismo. Ed. Pioneira. São Paulo, 1999.

${ }^{10}$ ANDRADE, José Vicente de. Turismo, fundamentos e Dimensões. São Paulo, Ed. Ática, 1998. 
econômica do deslocamento humano realizado em busca do prazer e da satisfação da necessidade do lazer. É uma forma de desligar um pouco da realidade rotineira que se vive nos dias atuais.

O turista, para a satisfação de suas necessidades precisa que outras pessoas forneçam serviços, pois este estará fora de seu local de residências e não tem total domínio dos serviços oferecidos. Assim o turismo está classificado economicamente como uma atividade pertencente ao setor terciário da economia, ou seja, ao setor de serviços.

Como modo de facilitar a vida de quem demanda os serviços turísticos, pessoas oferecem serviços, com o intuito de ser remunerado. Para o turista, a atividade é de prazer, para quem oferece o serviço é uma atividade econômica como muitas outras classificadas dentro dos setores econômicos.

Essas considerações aproximam o turismo das ciências aplicadas, como a economia e a administração, pelo seu caráter prático do saber produzido.

Essa atividade envolve uma gama vasta de outras atividades afins, que necessita, obviamente de um conjunto de conhecimentos para que seja mais bem produzida. $\mathrm{Na}$ verdade vários setores participam da cadeia produtiva, de uma forma ou de outra, se integram e se inter-relacionam quando de trata de fornecer os insumos necessários para o bom andamento da atividade. As atividades primárias, como a agricultura, pecuária, caça, pesca, colaboram com o abastecimento de alimentos. O setor secundário, através das indústrias de transformação de bens e a construção civil, contribuem para a criação e manutenção dos equipamentos turísticos. O setor terciário, com seus diversos segmentos, cuida de fornecer os serviços que fazem com que os outros dois setores anteriores possam chegar aos consumidores. Para que isso aconteça, cada serviço, com suas peculiaridades, colaboram para criar e manter uma atmosfera favorável ao bem estar do turista.

Para que a viagem possa ser considerada formalmente como turística, faz-se necessário que o deslocamento das pessoas seja realizado com um tempo mínimo de permanência no destino de 24 horas (embora a questão do tempo de permanência precise ser questionada em virtude, principalmente, da evolução dos meios de transportes e das comunicações) e, ainda, demandem serviços nos locais onde se está visitando.

O turista não pode exercer atividade remunerada, especificamente no local visitado, eis que se assim o for, não é considerado turismo. Mas, o que dizer do chamado 
turismo de negócios? A resposta pode estar no fato de que, ao apresentar ou estabelecer uma viagem em função dos negócios, há uma série de outros serviços vinculados à atividade turística, e, de uma maneira geral, também movimenta a economia. É o caso dos hotéis, bares, restaurantes, cinemas, clubes, etc., toda a infra-estrutura voltada ao turismo também estará disponível para as outras atividades que hoje são consideradas não-turísticas.

O estudo do turismo tem por principal motivo descobrir os desejos e anseios que fazem as pessoas saírem de suas residências e conhecer locais com hábitos e modos de vida diversos do vivido pelo turista. Também busca entender os hábitos das pessoas para que as mesmas, estando em um ambiente diverso do seu habitat normal, se sintam à vontade como se estivessem em sua própria casa.

O turismo também está sendo objeto de estudos das ciências sociais. Por envolver o relacionamento entre pessoas, com culturas diferentes, dentro de um espaço ocupado e limitado, os cientistas buscam entender e explicar este fenômeno.

Existe uma série de questionamentos realizados pelos diversos ramos das ciências sociais que estão sendo objeto de estudos para que se possa explicar aquilo que muitos entendem como o fenômeno turístico.

Os motivos pelos quais as pessoas se locomovem pode ser explicado pela busca de diversão, contemplação ou atividades afins, e estes estão relacionados ao fato do Homem sentir a necessidade de realizar algo fora do que é considerado rotineiro ou convencional. Há uma tentativa de se ocupar em atividades com o intuito de driblar ócio e o tédio. O direcionamento para atividades pode buscar o lúdico, o prazer, orientando também o tempo livre dos trabalhadores.

O tempo para o turismo é exatamente o tempo usado para descanso, fora da rotina, assegurando, neste caso, um alívio do nível de stress que prejudica o bom andamento das atividades normais do dia-a-dia.

Hoje, o que se busca com o estudo do Turismo, é entender os fenômenos e os detalhes do consumidor, para que os empreendedores possam oferecer serviços cada vez mais voltados à satisfação das necessidades desses clientes.

O turismo assim como as ciências sociais, que buscam entender as relações entre a natureza e o Homem, apresenta-se sob uma intensidade de variáveis, impedindo, em alguns casos, uma análise mais geral do fenômeno. 
O Turismo, como mais um posicionamento do conhecimento científico, procura se afirmar como um novo ramo do saber, se permitindo, assim como a Geografia, História, ou qualquer outra ciência, observar a realidade com métodos mais coerentes, não menos rígidos, estabelecendo um paralelo entre a teoria, que se interpõe como criadora de uma realidade ideal, abstrata; e a prática, a interferência da realidade tem com intenção melhor organização do espaço. É o eterno diálogo entre a ousadia e o conservadorismo, estabelecendo um meio termo entre esses dois extremos.

Os estudiosos do Turismo querem alcançar o status ciência, pois já produz interpretações próprias da nova área, assim como tomam emprestadas de áreas afins algumas explicações que favorecem uma conclusão adequada do fenômeno turístico em seus diversos aspectos.

É importante relatar que todos os conceitos aqui mencionados têm sua validade dentro do contexto no qual foram criados. Isso nos mostra que um conceito de turismo mais alinhado aos conhecimentos das ciências aplicadas convive tranqüilamente com os diversos conceitos produzidos a partir das ciências sociais.

Cada conceito citado tem sua razão de existir, assim como não anula o mérito das outras definições. Ao contrário, completam as lacunas deixadas pela especificidade de cada abordagem. Independente do conceito majoritário ou mais adequado ao turismo, o fato é que a população em geral necessita ser mais bem orientada e melhor incentivada a participar da vida da cidade, e conseqüentemente se enquadrar no mercado do turismo. Uma das estratégias possíveis é a inserção deste tema na educação pública. O orçamento participativo implementado pelo então Governador do Distrito Federal, Cristovam Buarque , foi um primeiro passo nesta direção na medida em que discutia com a população as alternativas e propostas orçamentárias capazes de melhorar a qualidade urbana das cidades do Distrito Federal, com vistas à atividade turística.

Por outro lado, verificamos, por exemplo, que a cidade de Camburiú - SC (fig. 02), bem como as cidades vizinhas, puderam incrementar o turismo nesta região, tendo como alternativa a criação de faculdades de Turismo.

Os estudos realizados nesta cidade, na área de turismo, bem como em áreas afins, como administração, foram fundamentais para melhorar a qualidade dos serviços oferecidos, aumentando a qualidade de vida da população local e a infra-estrutura das cidades próximas. Podemos verificar que a vocação para o turismo atraiu, assim como 
incentivou a criação de um grande número de pequenas empresas, passando a dar suporte ao crescimento do número de espaços para a acomodação dos turistas no período de alta estação.

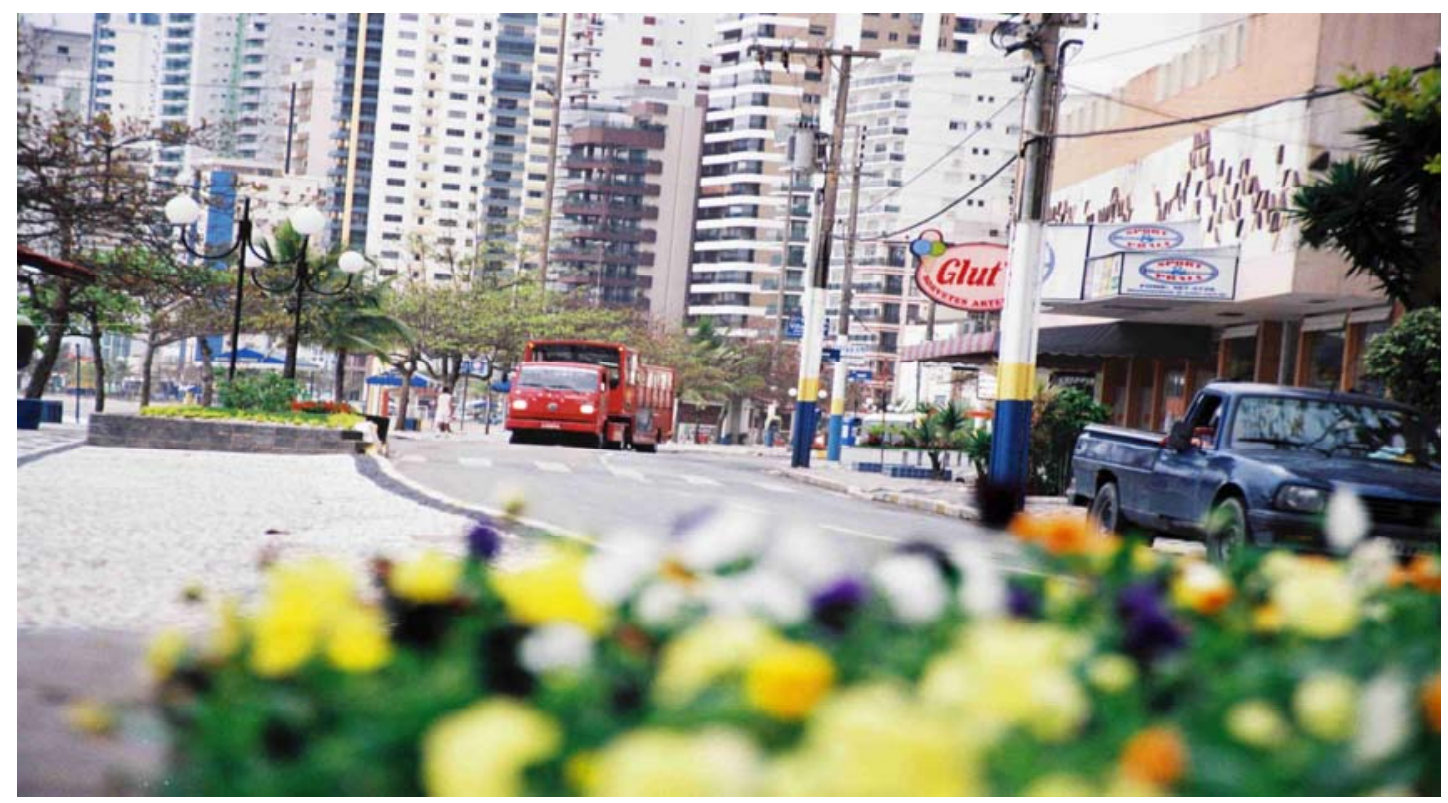

fig. 02 - Orla marítima do Balneário Camburiú-SC. Foto de Fernando Vargas, 2000.

\section{2 - PROBLEMAS NO DESENVOLVIMENTO DO TURISMO}

Existe uma gama enorme de problemas impedindo o desenvolvimento da atividade turística no Brasil. Assim como em outras partes do mundo, que podemos tomálos como inibidores para uma profissionalização desta atividade e, para serem solucionados, requerem uma mudança radical no modo de pensar de toda a população.

A falta de organização da sociedade coaduna com uma série de outros problemas que aqui explanaremos rapidamente. Os membros da sociedade ainda não se envolveram eficazmente com a atividade turística por ainda não vislumbrarem os benefícios que o mesmo pode trazer dentro de uma comunidade.

Se fosse fomentada a atividade turística em Brasília em apenas três modalidades (o cívico, o esotérico e o de aventura) poderia ser desenvolvida uma grande parte de atividades diferentes da cadeia produtiva, levando a uma dinamização de toda a economia, inclusive das regiões circunvizinhas.

Outras cidades trabalham com filões parecidos, como no caso do Rio de Janeiro, sede do Governo Federal até a transferência para Brasília, com a grande visitação em 
prédios públicos, sendo que alguns deles também transformados em museus abertos ao público. Em Ouro Preto, os prédios públicos do período da Inconfidência Mineira, hoje também estão abertos à visitação pública.

O turismo de aventura é bastante expressivo nas regiões sul e sudeste do país, destacando-se São Paulo, Rio de Janeiro e Minas Gerais, onde estão sendo estudados alguns projetos para a implementação de pólos de ecoturismo, pela grande quantidade de atrativos nos locais em questão. O Governo Federal, através do Ministério do Turismo, juntamente com o IBAMA desenvolvem um projeto de criação de Parques Nacionais e Pólos de Turismo, dois projetos distintos com o mesmo objetivo: a preservação do patrimônio natural brasileiro, através da conscientização dos moradores das áreas circunvizinhas, despertando para o potencial turístico para estas áreas. Este projeto ainda está em fase de estudo.

Outro grande dilema no desenvolvimento do turismo, que se apresenta como um grande ciclo vicioso, é a dificuldade em articular um planejamento governamental consistente (viável para execução) que possa articular os setores envolvidos no turismo e a sociedade, de modo a mostrar horizontes favoráveis aos investimentos suficientes à sustentação e inovações de produtos e serviços.

Os problemas de ordem política e social são, sem dúvida, os que mais emperram o desenvolvimento do setor. As dificuldades enfrentadas pela indefinição quanto à política de incentivo ao desenvolvimento do turismo mais coerente, o oferecimento à população de serviços básicos de saneamento com qualidade, tais como água potável, coleta de lixo e reciclagem, o tratamento do esgoto, melhoria dos serviços de saúde, onde a população possa ter acesso e, principalmente, uma educação voltada à construção da cidadania e da participação no planejamento e na fiscalização do dinheiro público, tudo isso faz o potencial turístico ser pouco aproveitado.

A violência de todo tipo, seja contra a pessoa, patrimônio ou no trânsito, apesar de não ser um fenômeno exclusivo do Brasil, aqui toma dimensões graves.

Notícias são veiculadas todos os dias e nos dão conta de que as atividades de todos os setores da economia sofrem com este mal. A sensação de segurança e impunidade deixa todos inseguros. São Paulo, e Recife, por exemplo, sofrem do mesmo mal, podendo ser em parte atribuído ao grande crescimento das cidades nos últimos 30 anos, sem o devido desenvolvimento socioeconômico dos habitantes recém chegados. 
Outro problema que também dificulta o desenvolvimento do turismo é o amadorismo de quem trabalha no setor. Conhecer a cidade ou saber negociar não é credencial para que o mesmo se firme na atividade escolhida dentro do turismo. A concorrência é impiedosa com todos aqueles que não estão atentos às mudanças que acontecem a cada momento no mercado.

O governo (seja municipal, estadual ou federal) precisa se atentar para os benefícios que podem ser trazidos à população em geral, promovendo o turismo de modo a integrar os diversos setores econômicos, resolvendo ou criando condições para a resolução de problemas estruturais do país, e, no nosso caso, no Distrito Federal.

O atrativo turístico é um dos conceitos que não se pode deixar de mencionar ao falarmos em turismo. É tudo aquilo que observamos no espaço, seja físico ou social, capaz de causar o sentimento de novidade a quem o observa.

A partir do momento que observamos uma porção do espaço que não estamos acostumados a vê-lo, e que este espaço, além de limitado, expressa uma dinâmica diversa da qual vivemos e nos causa interesse, chama a atenção, este passa a ser um atrativo. O projeto "Caminhos do Sol" gerado e em fase de estudos de viabilidade para implementação no estado de Goiás pode nos servir de exemplo, no que tange a integração de escola, empresas e governo na implantação de um modelo de turismo sustentável e que pode trazer renda e emprego à população local (ver folder desse projeto na fig.03).

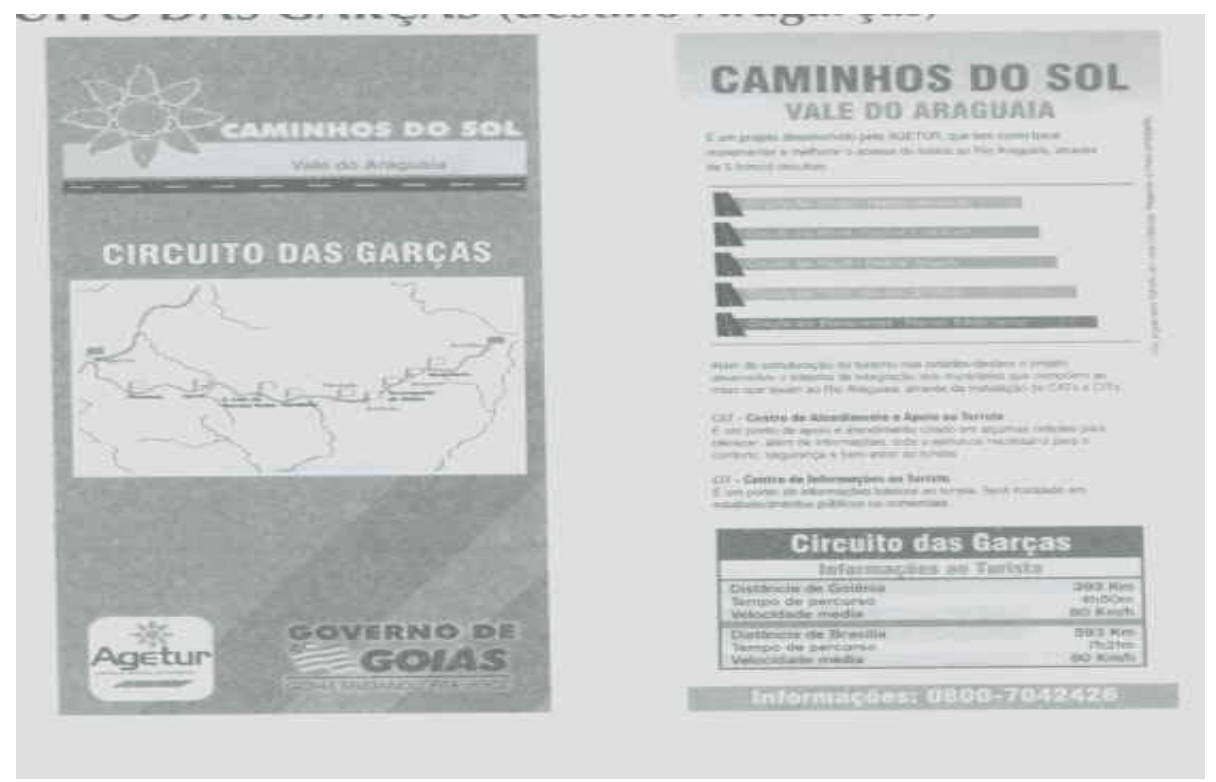

fig. 03 - CAMINHOS DO SOL - CIRCUITO DAS GARÇAS: folder do projeto realizado pela Setur-GO e Agetur em 2001. 
Em função do atrativo turístico que as pessoas buscam se deslocar em seu tempo relativamente ocioso. E atrativo pode ser natural (uma cachoeira, uma nascente, uma floresta, um parque, etc.), arquitetônico (a forma das casas e prédios, as soluções de arquitetura encontradas diante dos problemas enfrentados, etc), social (a cultura de uma comunidade), etc. Existem tantos atrativos quantos for à diversidade cultural e social que geram o exotismo. Como cada pessoa possui sua forma peculiar de organizar o espaço, assim como a sociedade inserida neste espaço, haverá sempre algo exótico no mundo a chamar a atenção de uma ou mais pessoa, capaz de transformar-se em atrativo turístico.

Trataremos a seguir de alguns aspectos de turismo ligados à educação, de uma forma específica, como o governo orienta seus funcionários das áreas de educação para o incentivo ao turismo no DF, como os professores do ensino fundamental e médio observam estas orientações, e um exemplo de como pode ser aplicado o conhecimento de interpretação cartas, mapas e representações gráficas para beneficiar e incrementar o turismo na região do Distrito Federal. 


\section{CAPÍTULO 2}

\section{O TURISMO E A EDUCAÇÃO}



fig. 04 - Imagem de Satélite de parte do Distrito federal, tendo Brasília ao centro, 1996.

Fonte: Nasa in site: www.brasiliense.hpg.ig.com.br 
Neste capítulo, trataremos do tema "o Turismo e a Educação" nos seguintes termos:

1. Em política pública para o Turismo no DF, será apresentado como as diversas esferas da Administração pública expõem a política para o turismo, sendo que na esfera federal será feita uma análise do plano de Turismo para o Brasil; no âmbito do Governo do Distrito Federal, apresentaremos o aspecto da linha de raciocínio adotada, e, mais especificamente, a aproximação desta com a educação pública do ensino fundamental e médio;

2. Em Turismo e o Ensino no DF estaremos mostrando alguns aspectos do ensino dos temas relativos ao turismo dentro da visão dos professores do ensino fundamental e médio, de maneira a entender as possibilidades de aplicação dos conhecimentos de turismo na prática, as dificuldades e possíveis soluções; por fim trataremos da questão do uso dos mapas para orientação, uma ferramenta que pode ser usada tanto na divulgação do turismo, quando para outros aspectos, tais como planejamento, controle e investimentos no setor.

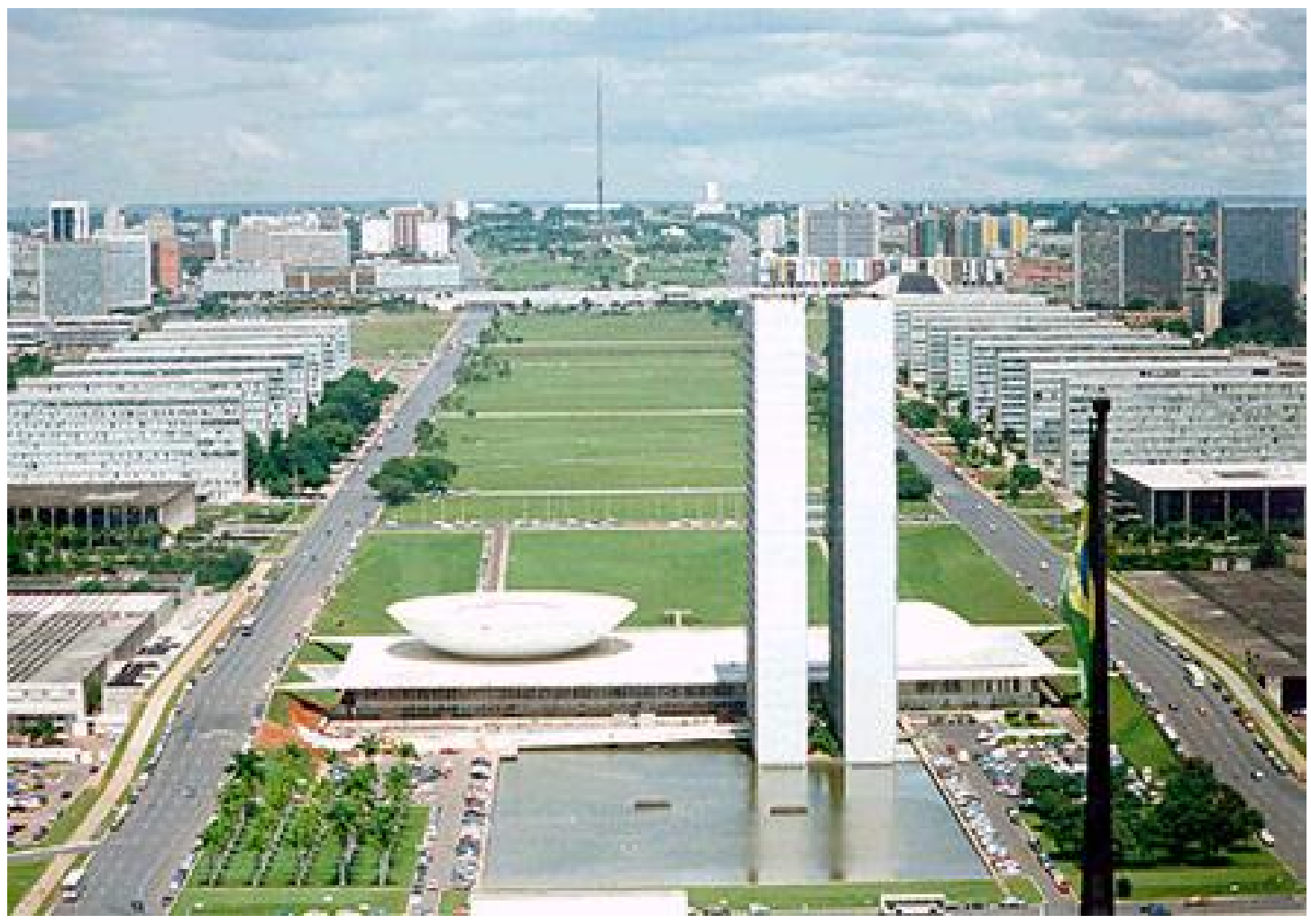

fig. 05 - Esplanada dos Ministérios fotografada por trás do Congresso Nacional, 2000 


\section{1 - POLÍTICA PÚBLICA PARA O TURISMO NO DF}

A política pública na área do Turismo se caracteriza como sendo um conjunto de fatores e medidas que colaboram para estabelecer um planejamento no nível governamental de implementação de diversas ações que facilitam e dinamizam as atividades e as ações empreendedoras privadas relacionadas ao turismo.

A política pública pode intervir nos diversos aspectos da vida da população de várias maneiras. Como afirma Ferraz (1992) a participação governamental se dá por três aspectos, o de participante, o de indutor e o de controlador.

A participação confere ao governo o ônus de exercer a atividade econômica dentro do conjunto da economia. Caracteriza-se pelo fato do governo colocar a máquina administrativa para exercer uma atividade econômica, principalmente em setores da economia onde a iniciativa privada não tem interesse em atuar ou que a atuação é feita de forma restrita. No Brasil, a participação do governo na economia do país vem se reduzindo nos últimos anos em virtude da política neoliberal implementada pelos administradores governamentais.

O aspecto indutor confere ao governo a parte de orientação das atividades do mercado, incentivando de diversas formas com que a iniciativa privada atue em certos setores da economia de uma forma específica.

Já o aspecto controlador, o governo, através da criação de normas, indica a maneira como deve se comportar o mercado dentro da economia.

Nesta parte do trabalho falaremos das políticas públicas voltadas para a fomentação do turismo no Distrito Federal e as perspectivas que estas políticas podem trazer para a população em geral no que consiste geração de empregos e renda, e, principalmente, como tudo isso se refletirá na economia da região. Nos diversos países do mundo, o turismo é uma atividade rentável que gera desenvolvimento econômico importante de modo a se manter um bom padrão de vida para a população beneficiada, revitalizando áreas que estavam deterioradas, criando novas funções para as áreas em questão. Como exemplo desta reestruturação temos a região portuária de Sydney, na Austrália, em Londres, na Inglaterra e em Whistler, Colúmbia Britânica, Canadá, a função turística passou a estar lado a lado com as funções anteriormente exercidas nos locais em questão (veja fig. 06, 07 e 08). 
O setor turístico se baseia numa atividade que produz o encadeamento de uma gama enorme de outras atividades relacionadas, que, no seu bojo, produz uma melhoria na vida econômica da região, embora nem sempre os resultados sejam de qualidade e distribuídos para toda a sociedade.

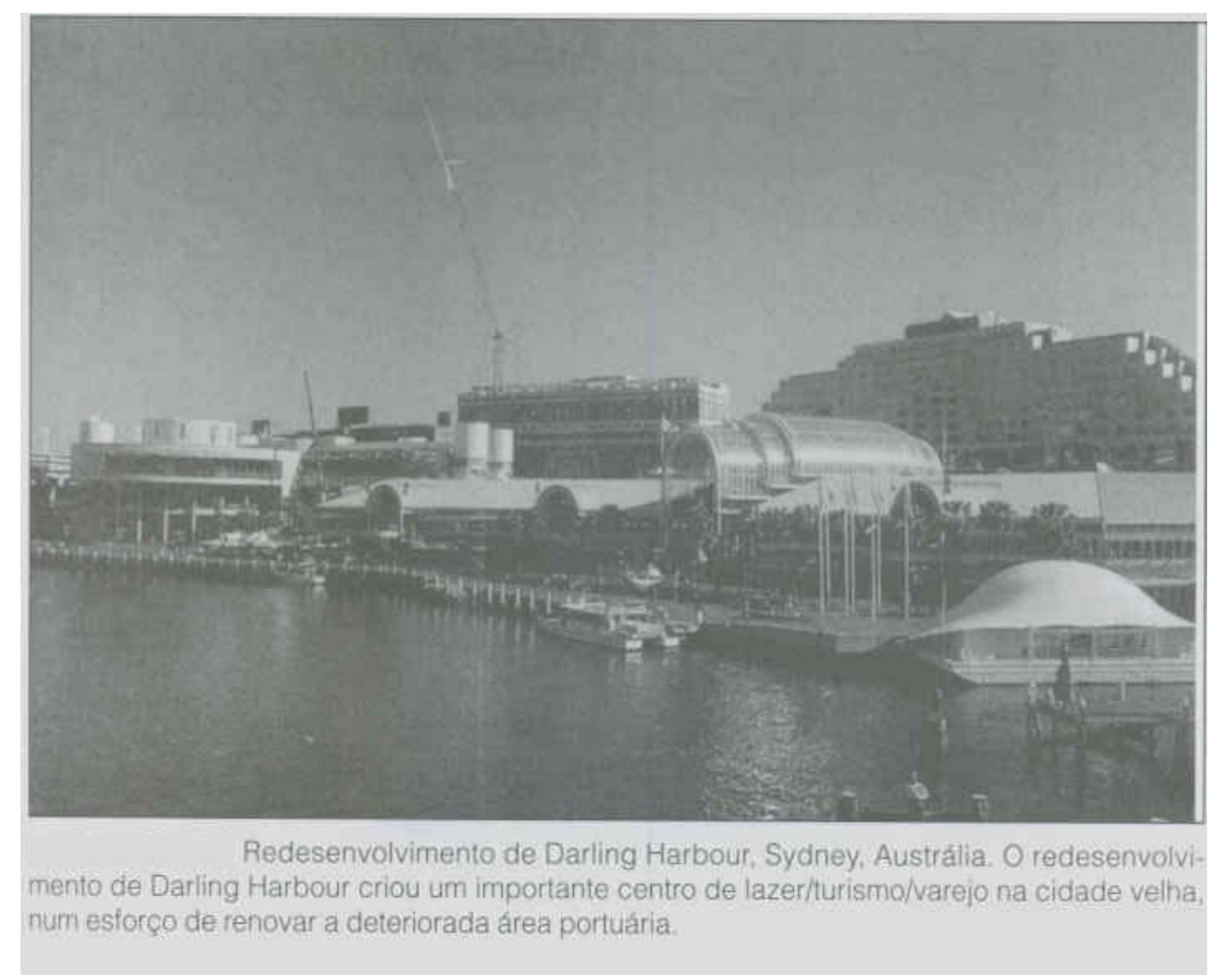

fig.06

Sob este aspecto, vamos buscar analisar os documentos produzidos pelo Governo Federal, o Plano Nacional de Turismo. Em linhas gerais, busca explicitar a linha de atuação do governo para o setor e conta com a participação de entidades, empresas de grande porte que representam o segmento turístico.

Os objetivos gerais são mencionados o desenvolvimento de produtos turísticos tipicamente brasileiros com qualidade, onde são contemplados em diversas peculiaridades (regionais, culturais e naturais), assim como criar condições e facilidades para o consumo dos produtos turísticos brasileiros nos mercados nacional e internacional. 


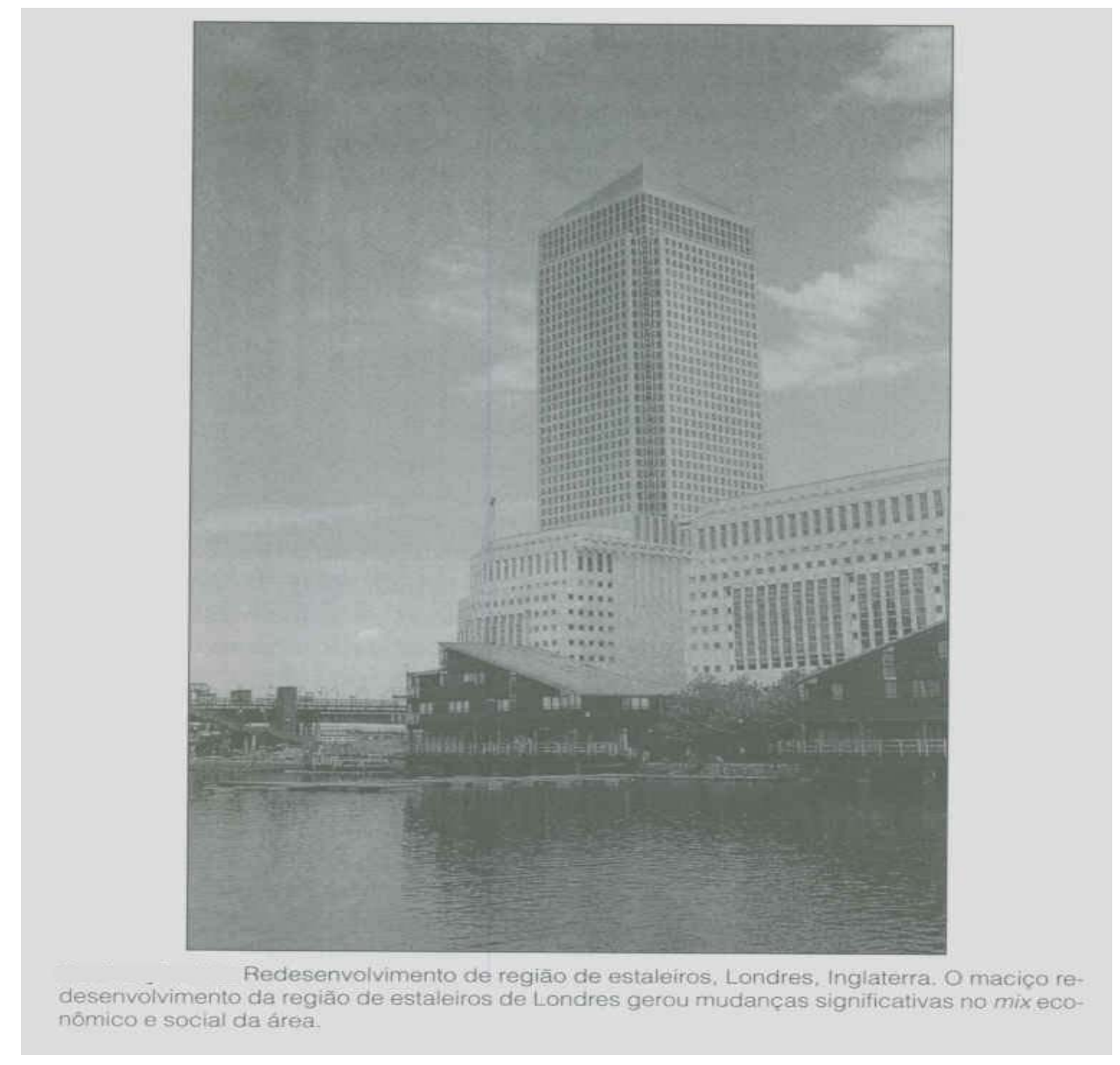

fig.07

Seguindo a política traçada no Plano Nacional de Turismo, também o governo local, à sua maneira, investe no turismo, focando suas ações para atrair o Turismo de Negócios e Eventos, o Turismo Místico, o Turismo Rural e, principalmente, o Turismo Cívico.

O pensamento do governo local é, através das diversas agências que estão ligadas ao turismo, promover a integração com os estados da região Centro-Oeste e criar rotas de visitação para o Turismo Místico, integrando os diversos estados da região, viabilizando este tipo de turismo.

A aposta com o turismo de negócios está na ampliação do Centro de Convenções e na proximidade com o sistema hoteleiro e principalmente com poder federal, como disse a Secretária Lúcia Flecha de Lima, em entrevista à Revista Fecomércio ${ }^{11}$.

${ }^{11}$ A íntegra da entrevista encontra-se na parte de anexos deste trabalho. 
O Turismo Cívico tem potencialidades que podem ser amplamente exploradas pelas diversas entidades ligadas ao turismo. A integração das diversas secretarias degoverno cria condições para o melhor dimensionamento do turismo em Brasília. A Secretaria de Educação, por exemplo, poderia criar programas onde os alunos da rede pública local e de outros estados visitariam a "Capital do País", com fins didáticos de conhecer o funcionamento dos Três Poderes na esplanada dos Ministérios (ver fig. 09).



fig.08

Tudo isso, para se viabilizar, deverá passar por um processo de divulgação e marketing de Brasília, das demais regiões administrativas do DF e do entorno, assim como a negociação de acordos entre os estados, viabilizando as estratégias mencionadas.

O que apresentamos até agora caracteriza a participação governamental no processo de divulgação da cidade e fomentação da atividade do turismo no DF. A participação de entidades não governamentais e do setor privado, como o Senac e Sebrae, também colaboram com o Turismo, principalmente no aspecto da formação técnico-profissional dos empreendimentos que estão diretamente ligadas a essa atividade. 




fig. 09 - Fotografia da Esplanada dos Ministérios vista da Torre de Televisão, 2001.

Fonte: $\mathrm{www}$. Brasiliense.hpg.ig.com.br

\section{2 - O TURISMO E O ENSINO NO DF}

Na intenção de fazer um diagnóstico do perfil do ensino do turismo no âmbito das escolas públicas no DF, fomos a campo estabelecer contato com os professores que lidam diretamente com a questão do turismo.

O objetivo do trabalho de campo foi entender a diversidade de formas de atuação dos profissionais em educação, das escolas públicas, ao abordarem a temática do turismo no Distrito Federal.

Entre os dias 20 a 24 de outubro de 2003, foram visitadas escolas de diversas cidades satélites e de Brasília, com o objetivo de verificar a forma de colaboração dos professores ao mostrar a importância do turismo local e possibilidades de intervenção da população para melhorar a imagem da cidade e assim aumentar a visitação da mesma. 


METODOLOGIA DE PESQUISA: ESCOLAS VITISADAS
\begin{tabular}{|c|c|c|c||}
\hline ESCOLA VISITADA & CIDADE & $\begin{array}{c}\text { TURNO } \\
\text { VISITADO }\end{array}$ & $\begin{array}{c}\text { N }{ }^{\circ} \text { DE PROF. } \\
\text { ENTREVISTADOS }\end{array}$ \\
\hline CEF 05 & GAMA & MATUTINO & $\mathbf{5}$ \\
\hline CEF 10 & GAMA & MATUTINO & $\mathbf{4}$ \\
\hline CEF 04 & GAMA & MATUTINO & $\mathbf{5}$ \\
\hline CEF GESNER TEIXEIRA & SANTA MARIA & VESPERTINO & $\mathbf{3}$ \\
\hline CEF 308 & SANTA MARIA & VESPERTINO & $\mathbf{4}$ \\
\hline CEF 304 & RECANTO DAS EMAS & MATUTINO & $\mathbf{3}$ \\
\hline CEF 03 & RIACHO FUNDO & MATUTINO & $\mathbf{2}$ \\
\hline CENB & NÚCLEO BANDEIRANTE & VESPERTINO & $\mathbf{4}$ \\
\hline CEF CANDANGOLÂNDIA & CANDANGOLÂNDIA & VESPERTINO & $\mathbf{5}$ \\
\hline CEF 410 & SAMAMBAIA & MATUTINO & $\mathbf{3}$ \\
\hline CEM AVE BRANCA & TAGUATINGA & MATUTINO & $\mathbf{3}$ \\
\hline CEM 04 & GUARÁ & VESPERTINO & $\mathbf{3}$ \\
\hline CEF 02 & BRAZLÂNDIA & MATUTINO & $\mathbf{4}$ \\
\hline CEM 01 & PLANALTINA & VESPETINO & $\mathbf{3}$ \\
\hline SETOR LESTE & BRASÍLIA & MATUTINO & $\mathbf{2}$ \\
\hline
\end{tabular}

Foram realizadas entrevistas com professores de várias disciplinas, dentre as quais os de geografia estavam inseridos (na pesquisa, pelas dificuldades de tempo e quantidade de professores por escola tivemos um professor por escola da disciplina geografia, sendo os demais participantes professores de outras disciplinas como história, projetos especiais, português, CFB e artes, num total de 53 professores). As entrevistas com os professores foram realizadas de modo informal, com perguntas abertas que possibilitassem uma análise qualitativa das respostas. No momento das entrevistas os professores estavam em atividades de coordenação.

As perguntas básicas feitas aos professores foram:

1. Como o turismo está sendo trabalhado pelos professores, em concordância com o que informa o currículo básico da Educação Pública do DF;

2. Como este ensino pode fazer com que se crie uma cultura turística;

3. Quais as dificuldades enfrentadas pelos professores ao implementar um plano de aula com o tema turismo;

4. Quais as principais alternativas para solucionar os problemas encontrados. 
Quanto à primeira questão, em todas as escolas visitadas, somente os professores de geografia tratam em suas aulas de questões pertinentes ao turismo. Os demais professores sequer mencionam o tema em suas aulas. As aulas acerca do Turismo são de forma expositiva, apresentando-o como mais um serviço do setor terciário da economia. Os professores de geografia dos Centros de Ensino Fundamental (CEFs), quando tratam de Brasília, apresentam mapas do DF, falam dos pontos turísticos e, quando é possível, organizam visitas a alguns dos pontos mencionados. "Nem sempre é possível conciliar as aulas de campo com o trabalho dos outros professores, que muitas vezes não conseguem adequar os objetivos das visitas realizadas aos temas tratados em sala", afirma a professora de geografia do CEF 05 do Gama.

As primeiras observações que foram realizadas mostram que os temas referentes ao turismo, previstos no Currículo Básico aplicado pela Secretaria de Educação do Distrito Federal, somente são tratados no currículo de geografia, no capítulo acerca do Distrito Federal. Tratam também da questão ao abordar os setores econômicos, dentro da especificação do setor de serviços.

Das escolas pesquisadas, os professores de Taguatinga e de Brasília tratam vagamente do turismo na questão do emprego e renda, tema muito atual. As demais escolas não associam a questão do desemprego tendo como saída o desenvolvimento do Turismo. .Fazendo uma análise mais apurada, o turismo poderia ser levantado nos Temas Transversais, que tratam da Educação para o Trabalho, podendo estar representado na busca de uma alternativa para a questão do emprego em geral, num momento em que a automação toma conta do sistema produtivo, dispensando e levando à informalidade trabalhadores antes empregados.

A segunda questão mencionada leva em consideração o entendimento do tema a ser assimilado por estes profissionais, as perspectivas e avaliações que podem ser tiradas da prática profissional para que se possa melhorar a atuação desses professores, fazendo com que esses sejam os principais articuladores na condução e preparação da sociedade para uma cultura do turismo. Observamos que nenhum dos professores possui uma visão muito clara do Turismo, transmitindo quase sempre o que é veiculado pela imprensa, sem muita discussão. "A experiência que possuímos com o turismo quase é resumida pela visão de turista que somos" afirma o professor de biologia do CENB.

Para a população observar melhor o benefício do turismo é imperativo que as pessoas vejam o que a cidade tem de melhor para mostrar e acreditem no potencial 
turístico da cidade, bem como trabalhem para manter a cidade organizada para isso. Além disso, o preço dos serviços turísticos na cidade se torna impeditivo para a população de baixa renda. É o que afirma os professores do Gama, Planaltina Santa Maria, Samambaia, Brazlândia e Recanto das Emas.

A necessidade de se estudar cientificamente o turismo esbarra nas dificuldades enfrentadas pelos professores no dia-a-dia em sala e nas coordenações. "O tempo usado nas coordenações para estudos é insuficiente para iniciar e concluir uma discussão de temas tão profundos como este. Além do quê, outros assuntos tomam a pauta da coordenação quase que integralmente.", afirma a professora de história do CEF 308 de Santa Maria, referindo-se ao preenchimento de diários, correções de exercícios, provas e avisos administrativos feitos pelos coordenadores locais.

Outro problema apontado pelos professores do Recanto das Emas e Riacho Fundo é a dificuldade de acesso aos livros sobre turismo, bem como a aquisição dos mesmos para uso em sala de aula. "Os livros fornecidos pela Secretaria de Educação são os livros didáticos e muitas vezes os mesmos não tratam do assunto. Quando o fazem, é muito superficial. Temos dificuldades em adquirir livros especializados, o nosso salário não nos permite tais ações", afirma o professor de geografia do CEF 304 do Recanto das Emas.

O acesso a mapas temáticos e cartas da cidade, atualizados, é mais um dos problemas enfrentados pelos professores no ensino de geografia. "Os mapas poderiam mostrar várias informações que somente com a descrição em livros não é de fácil visualização. Quanto mais atualizados os mapas, melhor podemos entender as alterações promovidas no espaço geográfico", afirma a professora de geografia do CEF 05 do Gama.

Já em relação às alternativas para solucionar tais dificuldades, todos os professores foram unânimes em afirmar que a Secretaria de Educação poderia organizar cursos ou painéis de estudo que pudessem abrir a discussão sobre os temas relativos ao Turismo, assim como fornecer uma bibliografia básica para trabalhar em sala, se possível com o apoio das universidades que possuem o curso de Turismo.

Os professores em geral sabem da potencial importância que o turismo pode representar na vida das pessoas, embora quase sempre estes profissionais conheçam melhor o turismo na condição de turista, e em geral muito pouco na condição de trabalhador nos setores que estão diretamente ligados ao turismo. A cultura turística como 
o governo prega e que gostaria de ver colocada em cena ainda é pouco entendida pela maioria dos professores.

Quase sempre cabe aos professores de estudos sociais (para a educação básica), e mais especificamente os de geografia (no ensino fundamental e médio) se encarregarem de trabalhar estas questões. Ainda assim o turismo está restrito a apresentar os pontos turísticos mais conhecidos do centro da cidade, como a Esplanada dos Ministérios, a Catedral, a Torre de TV e os Palácios da Alvorada e do Buriti.

Tais professores não promovem estudos mais aprofundados no campo do turismo, pois este ainda é um campo novo e que só agora desperta interesses. Muitos deles se mostram desorientados quanto a que rumo tomar nas discussões sobre turismo diante dos alunos, quer do ensino fundamental, quer do ensino médio.

A dificuldade de encontrar uma leitura básica em turismo, de orientação pedagógica, ainda é um tabu a ser quebrado. Nas coordenações, o espaço que deveria ser usado para fomentar discussões e buscar um melhor entendimento para relacionar os temas transversais (o turismo está integrado na proposta pedagógica como tema transversal) com as disciplinas de modo integrado e consistente, é usado quase que exclusivamente para discussões no campo administrativo, desvirtuando o real objetivo das coordenações. Nas escolas em que a coordenação acontece, os professores ainda não conseguiram compreender o caminho para as mudanças na metodologia de ensino, necessárias para atender às exigências da sociedade moderna.

Visitas a museus da cidade ou ao Parque Nacional da Água Mineral só acontecem quando os órgãos interessados oferecem algumas regalias, no caso dos museus, ou quando se trata de assuntos relativos ao meio ambiente e a preservação ecológica, no caso de visitas ao parque.

Há uma relativa dificuldade de entendimento de como a população pode auxiliar na promoção da cidade a ponto de ser transforma-la em atração turística e receber investimentos privados para aperfeiçoar esta condição.

Alguns professores também comentam assuntos relativos ao turismo quando jornais se dispõem a divulgar reportagens mostrando investimentos neste ou naquele setor. Recentemente foi veiculada uma reportagem onde o autor informava que o turismo de negócios e eventos, tais como congressos e feiras, movimentam consideravelmente a economia local, mas ainda passa despercebida pela maioria das pessoas que trabalham 
com a educação.

Outro ponto tratado pelos entrevistados diz respeito à falta de mapas atualizados e de boa qualidade (observa-se fig 10 que apesar de não ser propriamente um mapa, pode ser um primeiro passo para apresentação gráfica da cidade). Os mapas turísticos são ferramentas que contém informações gráficas para a visualização representacional de um certo espaço. É um conjunto de informações sobre uma localidade que pode ser acessada de forma remota, sem necessariamente conhecer ou estar de fato no espaço real. Eles podem ser considerados como de grande valia para a disseminação do turismo, pois apresenta visualmente o que se espera ver na realidade, poupando tempo na busca de informações.

Quando melhor orientados os turistas e a população em geral podem localizar mais rapidamente os espaços desejados sem perder tempo desnecessário com deslocamentos inúteis e informações duvidosas.

A disponibilidade de livros e trabalhos científicos atualizados é outro ponto que dificulta um melhor entendimento do turismo no DF. O que é mais grave, muitos professores sequer lêem coisas novas de forma mais aprofundada em qualquer outra área. A dificuldade de aquisição de tais livros, principalmente no que tange ao preço dos mesmos, muitas vezes é o principal elemento de entrave no aperfeiçoamento.

Outro aspecto que os professores se queixam diante do ensino do turismo é exatamente na falta de materiais didáticos que podem ser usados em sala de aula, tais como mapas, retroprojetores, assim como outras mídias mais avançadas, tais como o computador e datashows. A dificuldade de acesso a tais materiais se dá de uma forma tão burocrática, que desestimula o professor de usá-las, tamanhas as dificuldades que são criadas pela sistemática implantada.

Isto tudo nos leva a pensar que as instituições de educação deveriam promover o diálogo entre elas (uma vez que até entre as escolas na mesma cidade os professores da mesma disciplina sentem dificuldade de discutir assuntos comuns), inclusive buscando a Universidade, mesmo para assistir cursos, palestras ou para receber dicas de livros para auxiliar o planejamento e execução das atividades. 


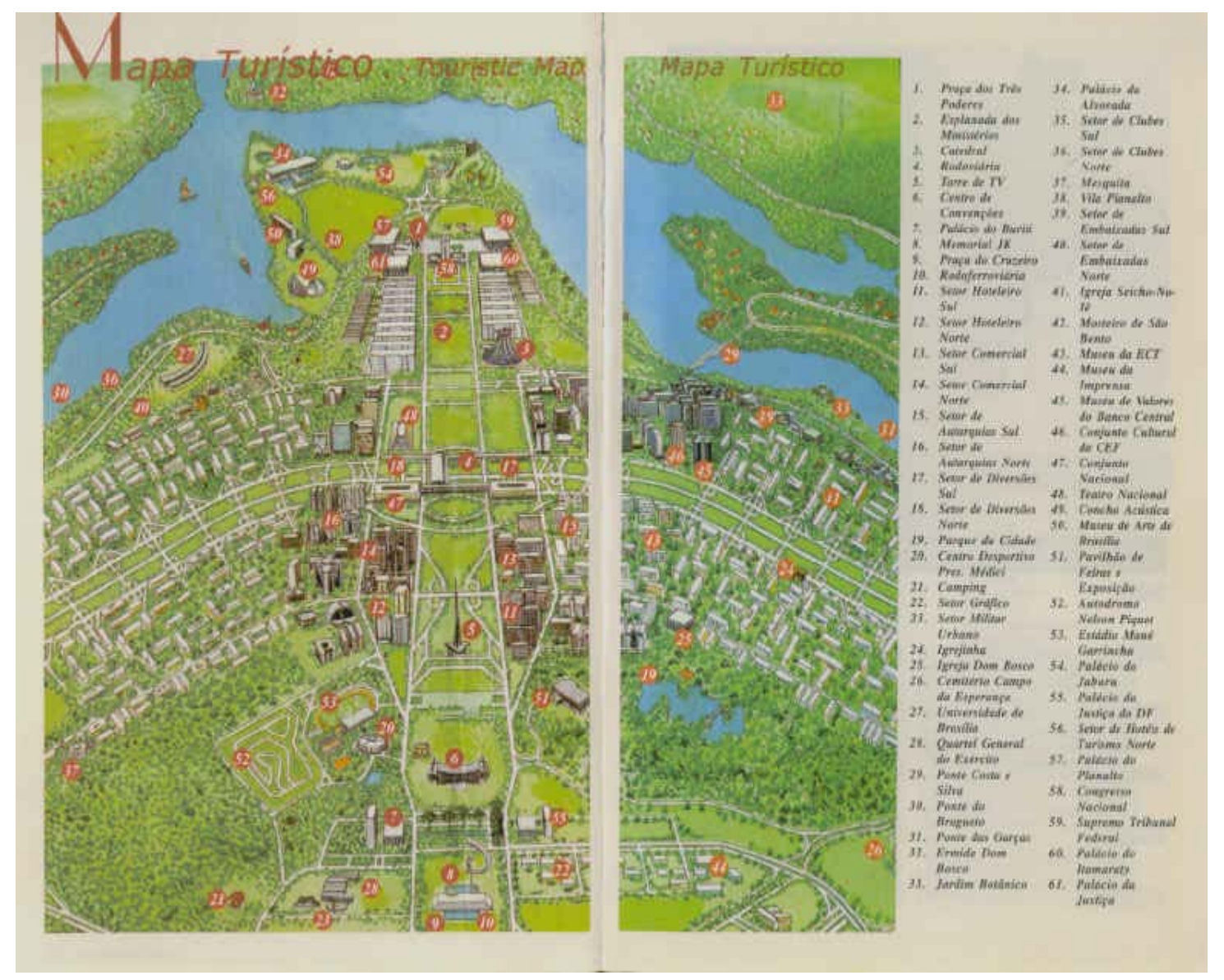

fig.10 - Representação em perspectiva de Brasília, onde são apresentados vários pontos turísticos da cidade. Fonte: Guia turístico de Brasília, 2002.

\section{3 -O USO DE MAPAS NO ENSINO E NO TURISMO}

Os mapas turísticos no Brasil são pouco utilizados no Brasil, primeiro pelo acesso da grande maioria população brasileira a tais mapas, depois pela dificuldade em interpretar tais informações contidas nos mapas. Pela dificuldade de manuseio constante dos mapas por parte da população, devido principalmente à baixa escolarização, esta cria outros artifícios para dirimir suas deficiências em se orientar no espaço do DF. 


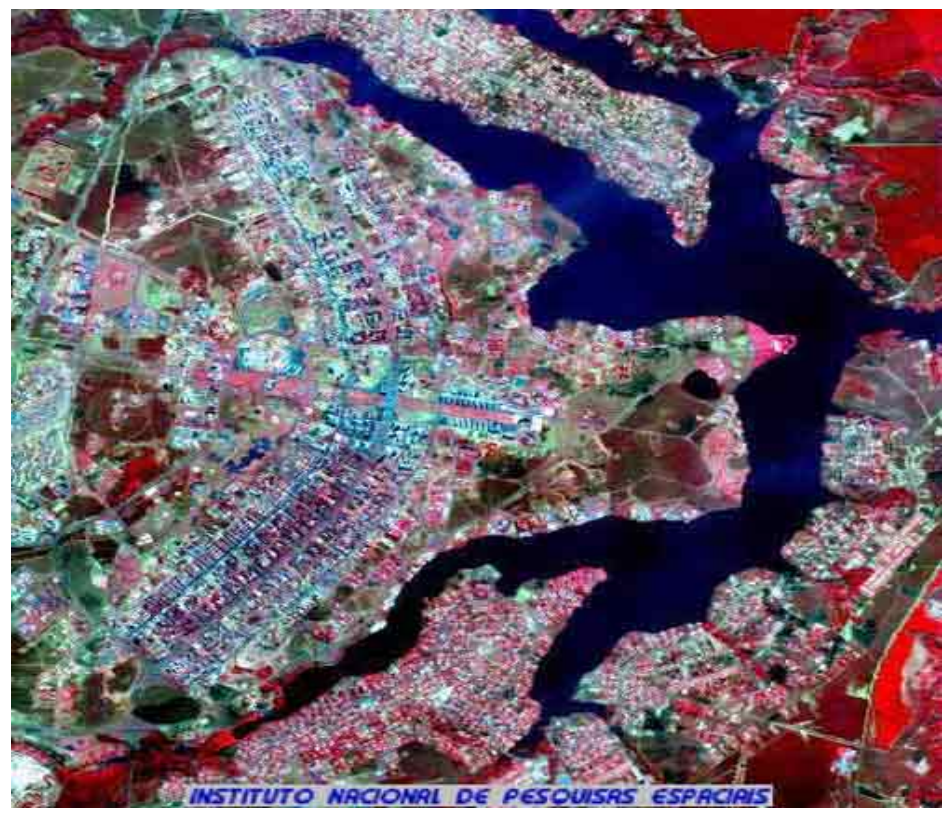

fig. 12 -Imagem de satélite da área central de Brasília. Fonte: Inpe., 1998 (in site: uww.prometeus.itsa.com.br)

Os mapas que estão disponibilizados aos professores trabalharem o Distrito Federal, em nenhum momento aponta para outros locais que podem ser visitados como atração turística. Há os mapas rodoviários, com escalas de 1:100.000 em que as cidades aparecem como simples "manchas" na paisagem, oferecendo uma visão geral das cidades, sem apontar locais específicos que podem despertar o interesse dos alunos em conhecer a cidade.



fig. 13 - Mapa das Regiões Administrativas Distrito Federal fonte: Codeplan ( in site: unw.prometeus.itsa.com.br) 
Vários aspectos relativos ao turismo não são de conhecimento da grande maioria dos educadores. A conscientização da população na preservação do patrimônio histórico e arquitetônico da cidade, assim como a valorização e registro da memória dos habitantes que participaram da construção e consolidação da capital do país não é sequer comentada, quanto mais trabalhar no sentido de reverter à tendência cruel do esquecimento dos tempos da epopéia da construção de Brasília.

Fechar-se no próprio meio é uma maneira de se perder diante da grandeza do conhecimento, ou por não buscar alternativas com as idéias de outros, ou por deixar de divulgar os conhecimentos alcançados, tornando-os públicos dentro do trabalho realizado.

Uma das formas mais práticas de promover a consciência para o patrimônio turístico é visitá-lo. Museus e prédios públicos estão abertos à visitação e são possíveis e acessíveis, necessitando de um contato prévio com o local de visitação desejado.

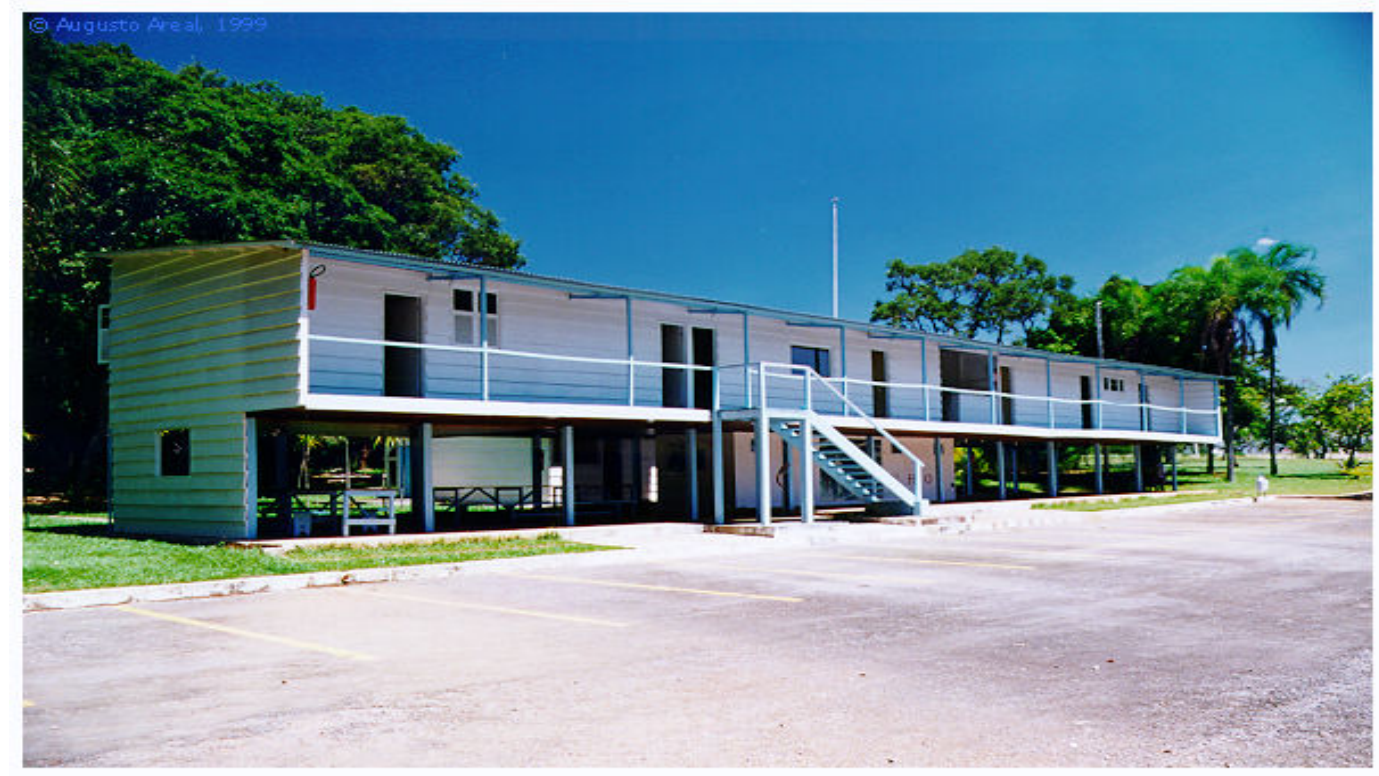

fig. 14 - Foto do Catetinho - Primeira construção realizada em Brasília no período da construção da capital, 2002

Ao tratarmos do acesso a mapas por parte dos visitantes visando localizar os diversos pontos turísticos no Distrito Federal, devemos ter em mente que os mapas são importantes meio de divulgação dos espaços turísticos. É uma excelente maneira de se buscar uma noção do que se pode encontrar dentro daquele espaço, antes mesmo de conhecê-lo. 
A geografia tem um interesse especial na área do turismo, uma vez que este está intimamente ligado ao consumo do espaço e do relacionamento com este.

Podemos tranqüilamente afirmar que o turismo é uma prática social aliada a um relacionamento com o espaço.

Observamos a fala de grande parte dos turistas, bem como daqueles que tomaram a cidade por sua recentemente, há uma grande dificuldade em se localizar os endereços de diversos pontos turísticos, dentro e fora do centro de Brasília.

Uma das dificuldades encontradas por quem procura endereços no Distrito Federal, está justamente no fato da cidade estar segmentada em setores e que tais setores são identificados por siglas.

As siglas, que ao mesmo tempo facilitam a pronunciação dos diversos endereços, em muitos casos criam dificuldades de locomoção pela cidade, principalmente para aqueles que tem menor grau de instrução. Siglas como SGAS, SCEN, SQS, SCLN, SDS, SHIS, SRTVS ${ }^{12}$, para quem não conhece ou quem ainda não está acostumado com a rotina das cidades no DF, não faz muito sentido, assim como é objeto de grande frustração, quando se fala em visitas individuais, sem o acompanhamento de guias.

Uma parcela considerável da população no Distrito Federal utiliza-se como meio de locomoção o transporte público. E para muitos destes usuários as referências para localizar os endereços corretamente é justamente o trajeto percorrido pelos ônibus. Uma característica que é peculiar no DF, principalmente em Brasília, que os ônibus que transportam passageiros em linhas regulares passam em nos corredores centrais da cidade. Como geralmente o ponto de descida é distante do local de visitação, há um desestímulo muito grande do uso deste tipo de transporte pela população que possui um melhor poder aquisitivo. O que realmente importa aqui é que os pontos de embarque e desembarque do transporte, e principalmente o trajeto percorrido pelos ônibus em geral se transformaram em ponto de referência para a localização de vários atrativos turísticos.

${ }^{12}$ Os significados das siglas mencionadas são: SGAS - Setor de Grandes Áreas Sul; SCEN Setor de Clubes Esportivos Norte; SQS - Super Quadra Sul; SCLN - Setor Comercial Local Norte; SDS - Setor de Diversões Sul; SHIS - Setor de Habitações Individuais Sul (Lago Sul) e SRTVS Setor de Rádio e Televisão Sul. 


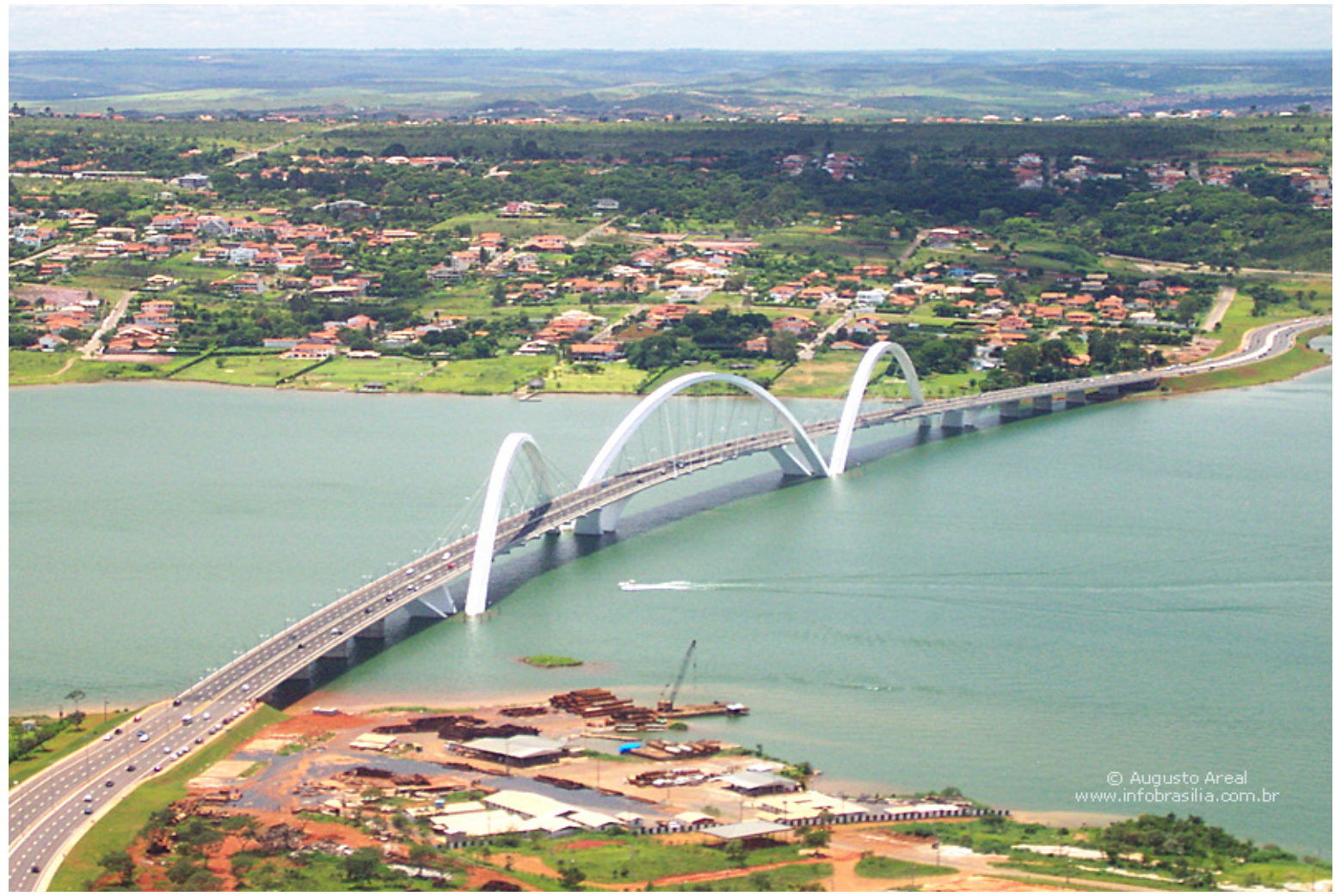

fig. 14 - Foto da Ponte JK fonte: www.brasiliense.hpg.ig.com.br

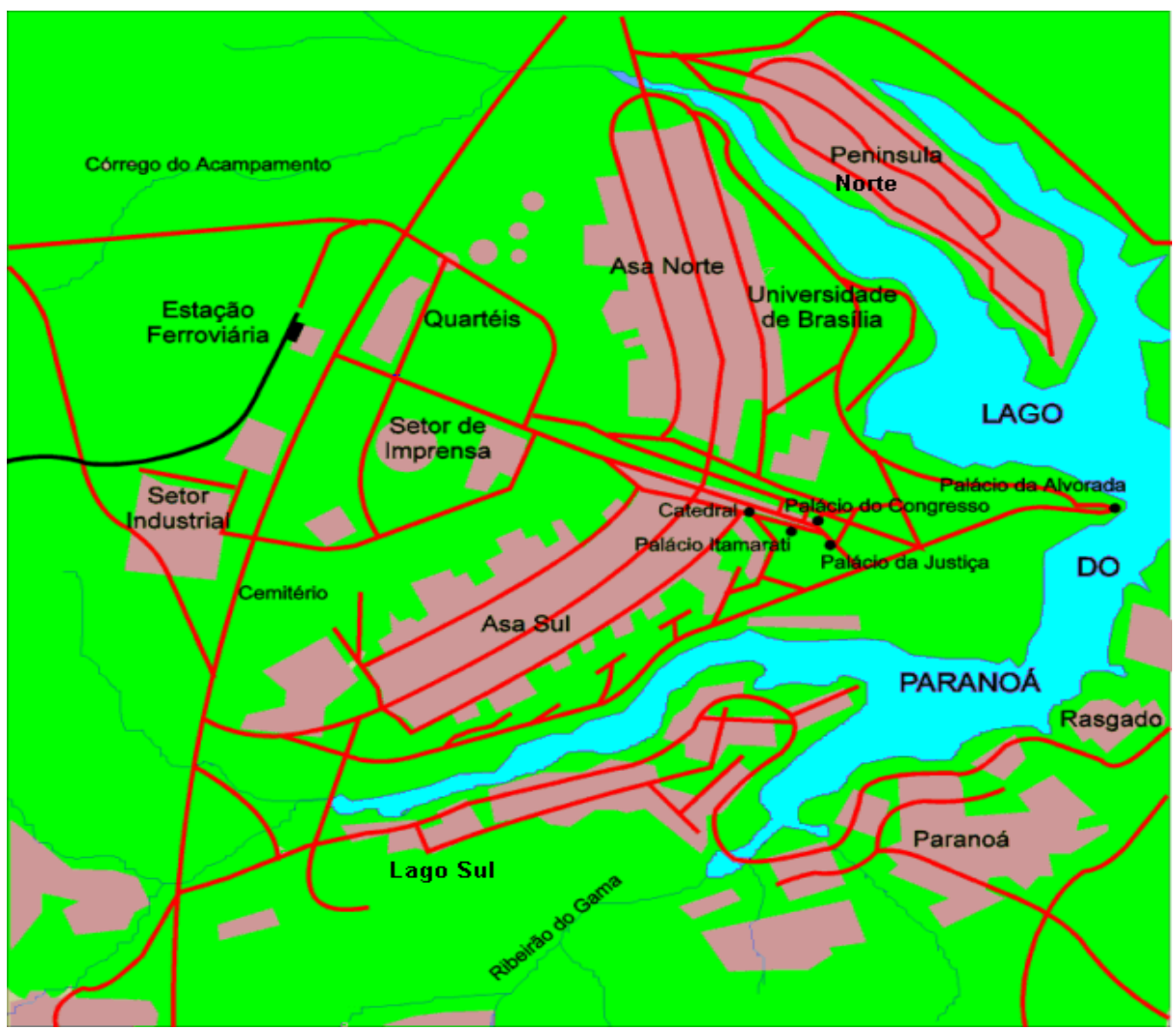

fig. 15 - Mapa rodoviário de Brasília- principais rodovias

fonte: CODEPLAN, in site: umw.viaecológica.com.br 


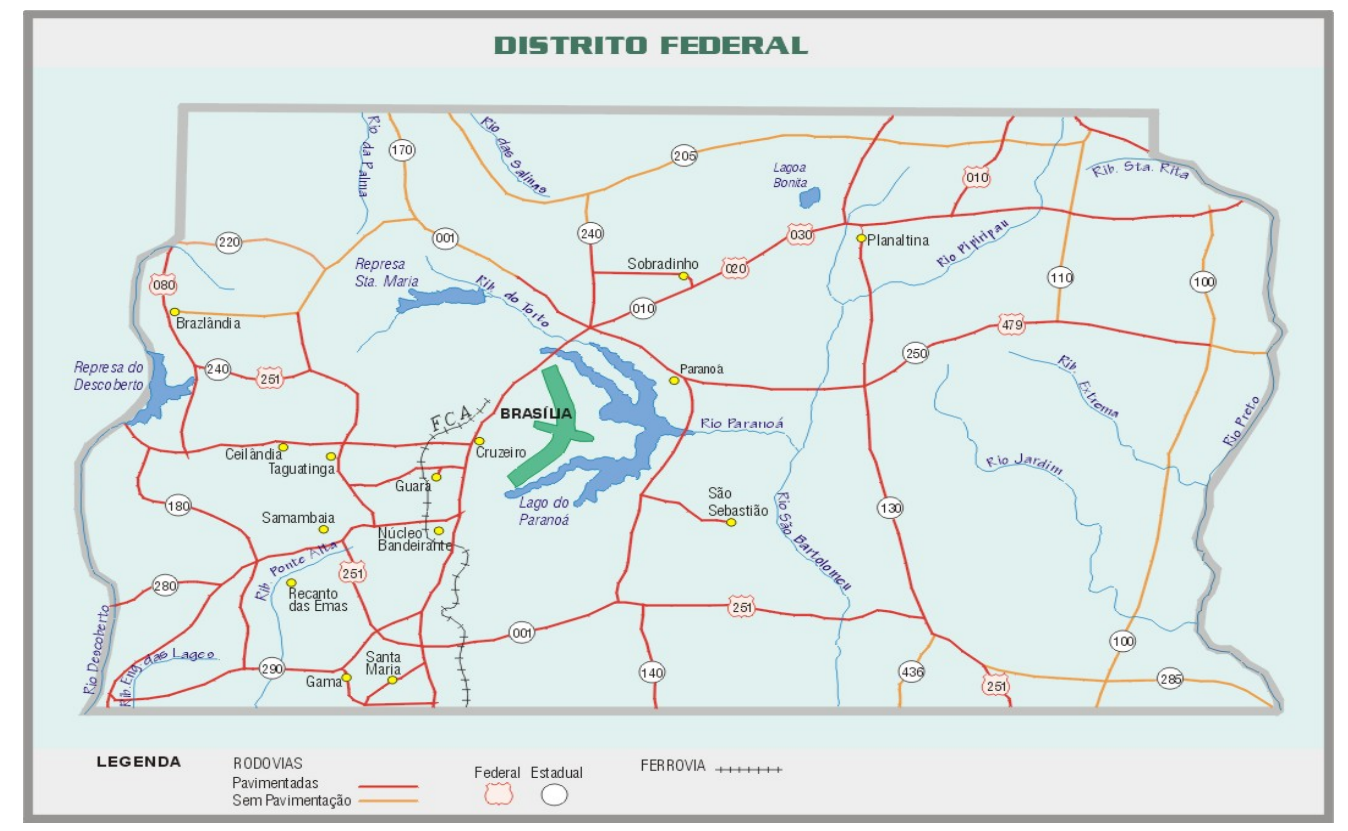

fig. 16 - Mapa rodoviário do DF - principais rodovias fonte: CODEPLAN, in site: www.viaecológica.com.br

Existem vários pontos turísticos no Distrito Federal que não são devidamente explorados porque estão distantes dos pontos de Ônibus. E quando se trata de viagens direcionadas, sob a orientação de guias turísticos, tais pontos são deixados de lado por opção dos pacotes de viagens, que se preocupam em explorar os pontos mais ao centro da cidade.

Tal procedimento das empresas que tem como ramo de atividade a atividade turística, deixa a desejar quando falamos em conhecer a cidade. Mesmo sendo tratado de forma deficiente, ainda assim é uma iniciativa louvável, mesmo que básica, e à medida que o serviço vai se profissionalizando e se especializando, mais aperfeiçoado e mais diversificado vão se tornando as atenções para a cidade.

Nas aulas no ensino fundamental e médio é possível trabalhar os mapas (fig. $15 \mathrm{e}$ 16), cartas, fotografias de satélite (fig.19) e representações do espaço geográfico, através do estudo em campo com a localização dos pontos no mapa. 




fig.17 e 18 - Áreas que podem ter um potencial turístico, se melhor conservada e trabalhada para isso. Fonte: CORREIO BRASILIENSE - 21/09/2003

Passaremos agora as considerações finais, onde faremos um levantamento dos conhecimentos abordados no decorrer deste trabalho, bem como faremos algumas recomendações acerca das dificuldades encontradas no desenvolvimento dos trabalhos nas atividades de turismo e educação para o turismo.

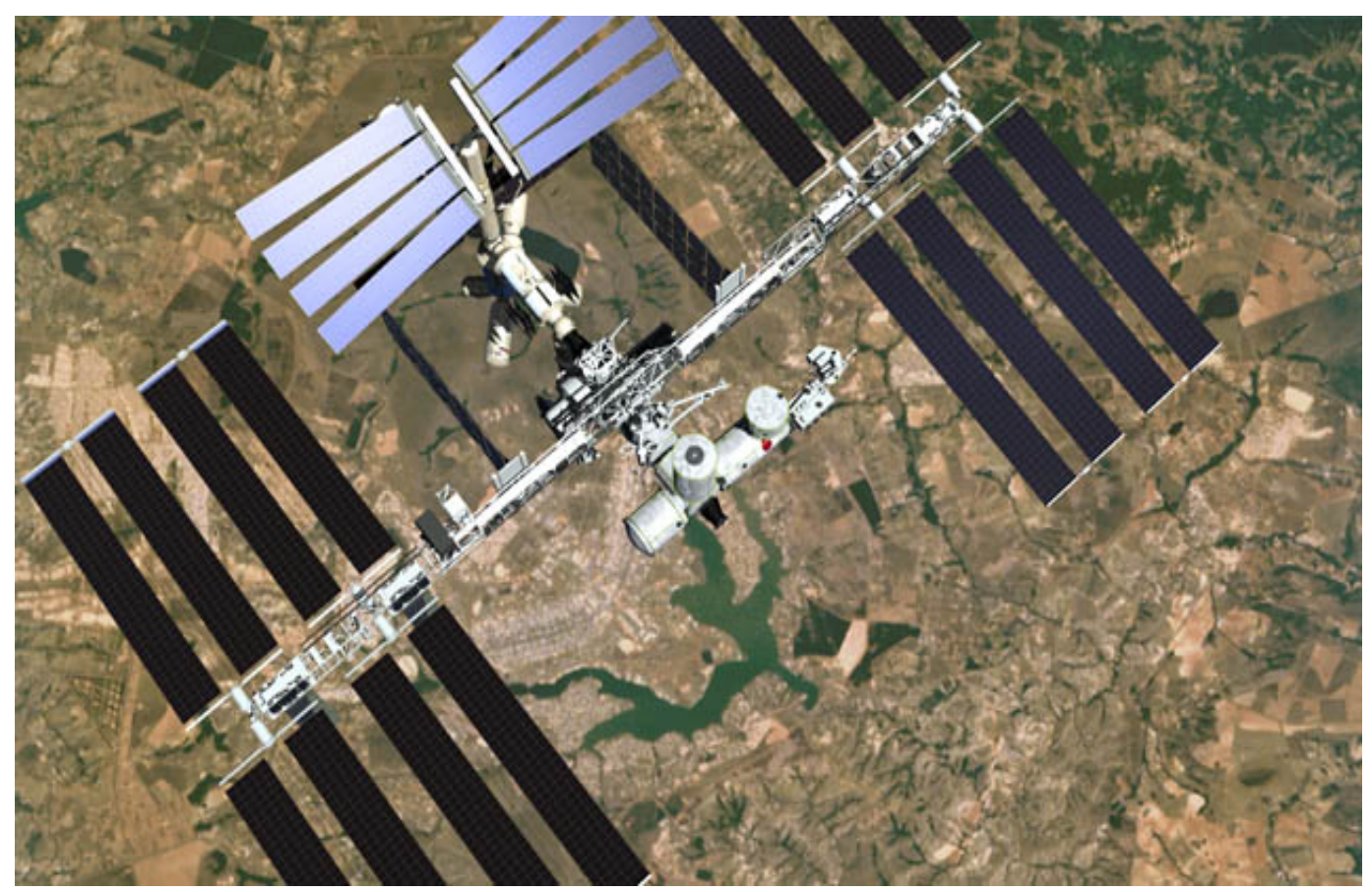

fig. 19- llustração digital mostra a estação espacial internacional sobrevoando Brasília, pode-se notar o Lago Paranoá e as duas asas do Plano Piloto. 2000.

Fonte: site unw.brasiliense.hpg.iq.com.br 


\section{CAPÍTULO 3}

\section{CONSIDERAÇÕES FINAIS}

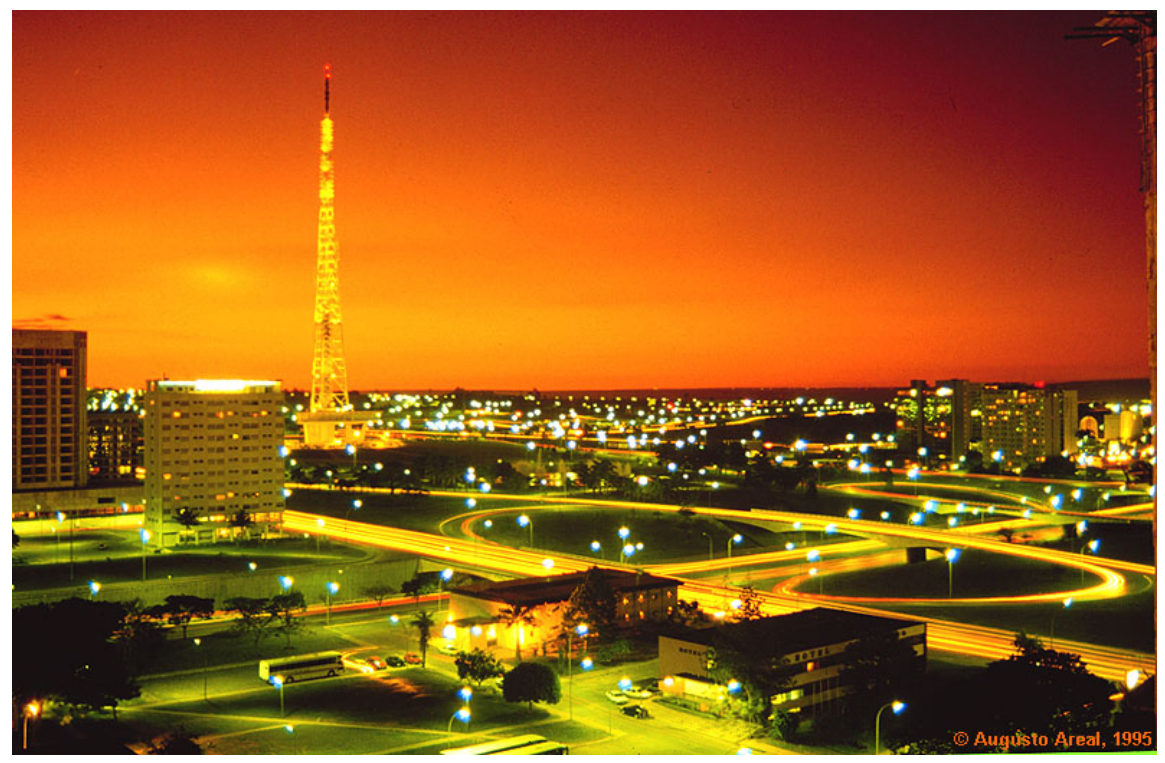

fig. 20 - Brasília ao cair da tarde

fonte: $u w w$.brasiliense.hpg.ig.com.br 
Nas considerações finais buscaremos fazer uma análise do que foi apresentado no decorrer do trabalho.

Será dividida em duas partes:

1. CONCLUSÕES: faremos uma exposição do que foi apresentado neste trabalho, de maneira sintética;

2. RECOMENDAÇÕES: diante doa problemas e dificuldades apontadas no trabalho, elegemos alguns caminhos que podem ser seguidos e se implementados, podem alterar para melhor o quadro do turismo e a educação para o turismo, incentivando a população a conhecer melhor a cidade e trabalhar em prol de mostrar, de forma mais hospitaleira que este é um bom local para se visitar.

\section{1 - CONCLUSÕES}

O Distrito Federal, assim como a sua Região do Entorno, pode ser um espaço de grandes oportunidades para a exploração do turismo. Os problemas encontrados no decorrer desta pesquisa, além de dificultar a criação das condições para nascer tais oportunidades, a divergência quanto à forma de implantação do modelo de turismo cria uma certa sensação de insegurança quanto ao futuro da atividade do setor na região.

O entendimento das autoridades hoje é de buscar uma continuidade no trabalho, porém com correção dos rumos que esta considera equivocado, realizando investimentos de forma mais generosa no que espera ser a tendência de desenvolvimento do turismo de Brasília.

É importante que se invista no que dá mais lucros para a cidade. Cabe salientar que o turismo tem que cumprir um aspecto social dentro da cidade, como promover a integração dos diversos segmentos sociais, promover riqueza, gerar empregos e renda para a população depender menos dos programas sociais do governo.

O investimento em setores que hoje são quase artesanais, oferecendo condições técnicas e estruturais para que o pequeno investidor possa canalizar seus recursos e suas energias para gerar condições para o crescimento e desenvolvimento do seu próprio negócio e, principalmente, para dar oportunidade a outros investirem também. 
O conhecimento sobre os diversos elementos abordados na disciplina turismo dá uma certa vantagem àqueles que o busca. Antes de qualquer coisa tal conhecimento deve estar à disposição de todos e que todos possam ter acesso aos estudos e pesquisas, uma vez que devemos valorizar o conhecimento produzido e que este possa ser implementado e verificado a sua eficácia.

A integração turismo-conhecimento-educação aqui em Brasília deve ser incentivada com muita força para efetivamente se criar uma "cultura turística", não somente freqüentando com mais assiduidade os pontos turísticos, como oferecendo condições para que os visitantes de outros lugares possam se sentir acolhidos e terem boas lembranças do DF, não somente pelo que viram, mas pela qualidade da acolhida que tiveram, e que retorne mais vezes, trazendo os recursos preciosos que tanto disputamos.

Cumpre salientar que em tal integração que falei anteriormente, o setor educação, que tem a tarefa de distribuir o conhecimento adquirido nas universidades e no mercado, deve ser mais bem assessorado.

Por ser um setor pouco conhecido, mas em franca evolução, não pode ser considerado um modismo no que tange aos investimentos públicos e privados. Cabe aos profissionais de educação criar uma cultura do turismo, não somente no sentido e visitar outras localidades, mas, no sentido de oferecer o que temos de melhor com excelência na qualidade dos produtos apresentados.

Para que isso seja efetivamente realizado, há uma necessidade e equipar melhor a cidade com sinalização e mapas da cidade eficazes, sem permitir que se polua a cidade com excesso de informações.

Quando às escolas públicas e seus profissionais, há um anseio muito intenso de equipamentos mais modernos que o simples quadro negro e giz. Os professores podem ser mais bem orientados tanto nas coordenações quanto em sala de aula se houver uma melhor orientação, não só em relação à didática, como também ao nível dos conteúdos abordados em sala. Cursos para os professores e orientadores para que os mesmos busquem uma melhor qualidade na preparação do trabalho em sala é o principal desejo de tais profissionais.

Outra perspectiva que os professores gostariam de ser contemplados é o acesso a 
mapas e informações mais detalhados do DF e Entorno, assim como um acervo bibliográfico mais atual acerca dos temas aqui abordados neste trabalho.

Vários projetos que são promovidos por diversas entidades no sentido de promover a cultura da cidade são importantes. Visita a museus, parque e eventos promovidos na cidade são provas vivas de que parcerias com tais entidades estão no caminho certo. A preparação e a conclusão das visitas estão a cargo dos professores.

Em suma, podemos dizer que este trabalho foi útil no sentido de diagnosticar os seguintes problemas que emperram o desenvolvimento de uma cultura do turismo no DF:

- A dificuldade da população em conhecer a cidade de forma mais aprofundada;

- A violência, como um fator que afugenta o turista;

- A falta de roteiros variados para a visitação da cidade;

- A visão das autoridades em somente trabalhar o aspecto do turismo numa visão patrimonial, com construções e reformas dispendiosas.

- A dificuldade de acesso a mapas da cidade e mapas turísticos da cidade;

- A dificuldade no acesso aos prédios públicos para visitação;

- O pouco incentivo do governo para que a população participe da vida turística da cidade;

- A dificuldade de acesso dos professores a livros, cursos e metodologias que incentivem a criação e disseminação de uma cultura do turismo no DF.

\section{2 - RECOMENDAÇÕES}

O que podemos trazer como sugestões que podem melhorar o aspecto do turismo no DF, de maneira a se observar uma melhoria na qualidade dos serviços prestados e na receptividade do turista:

- Que o Governo incentive a educação para o turismo, com cursos, palestras, incentivando e divulgando materiais voltados ao turismo, assim como valorizando a cidade;

- Que se incentive a visitação mais freqüente dos museus e outros locais de interesse turístico pelos alunos das escolas públicas do DF; 
- Que se busque incentivar a produção de materiais voltados ao turismo por parte dos alunos das escolas públicas do DF;

- Que se equipe melhor as escolas com livros mais específicos de turismo, para os professores melhorem a qualidade das aulas que incentive o turismo no DF;

- Que possa ser disseminado o acesso aos mapas turísticos da cidade, assim como facilitar o acesso da população aos diversos prédios públicos, inclusive nos fins de semana;

- Que os habitantes da cidade possam acreditar que a cidade tem um grande potencial para o turismo e que trabalhem para que isso ocorra.

A criação da chamada cultura do turismo é de vital importância para que todos se envolvam em melhor produzir a cidade para o consumo dos que visitam e, conseqüentemente, melhores condições para a própria população local, pois preparando a cidade para o turista, estaremos fazendo isto para nós mesmos, uma vez que somos os beneficiários do que estaremos produzindo por aqui. 
ANEXO 


\section{Turismo com charme e elegância}

Para cumprir a missão de desenvolver o Turismo em Brasília, a secretária de Turismo do DF, Lúcia Flecha de Lima, conta com sua experiência internacional, parceiros empresariais e governo

Por Wanessa Saia

A

experiência adquirida na vida diplomática, nos anos em que acompanhou o esposo, Lúcia Flecha de Lima utiliza diariamente no cargo que hoje desempenha à frente da Secretaria de Turismo do Distrito Federal. Nos anos em que esteve fora do país, a secretária participou ativamente de importantes projetos sociais, contribuindo na divulgação da imagem do Brasil no exterior.

Com a missão de desenvolver o Turismo na capital da República, Lúcia Flecha de Lima fala nesta entrevista sobre os projetos para incentivar o turismo em Brasília; os investimentos voltados para incrementar o Turismo de Negócios; a reforma do Centro de Convenções; as parceiras da Secretaria; e a forte identidade que tem com a cidade que viu ser construída.

Revista Fecomércio: Quando se fala em vocação econômica de Brasilia, o turismo aparece como uma das grandes opções. Qual o potencial do turismo no DF?

Lúcia Flecha de Lima: Brasília tem um grande potencial para o turismo de Eventos e de Negócios. Trata-se da capital do país, localizada no centro do Brasil, uma cidade com alta qualidade de vida e um trânsito razoável. Possui uma boa infraestrutura, e, como parte desta, o Centro de Convenções, muito bem localizado.

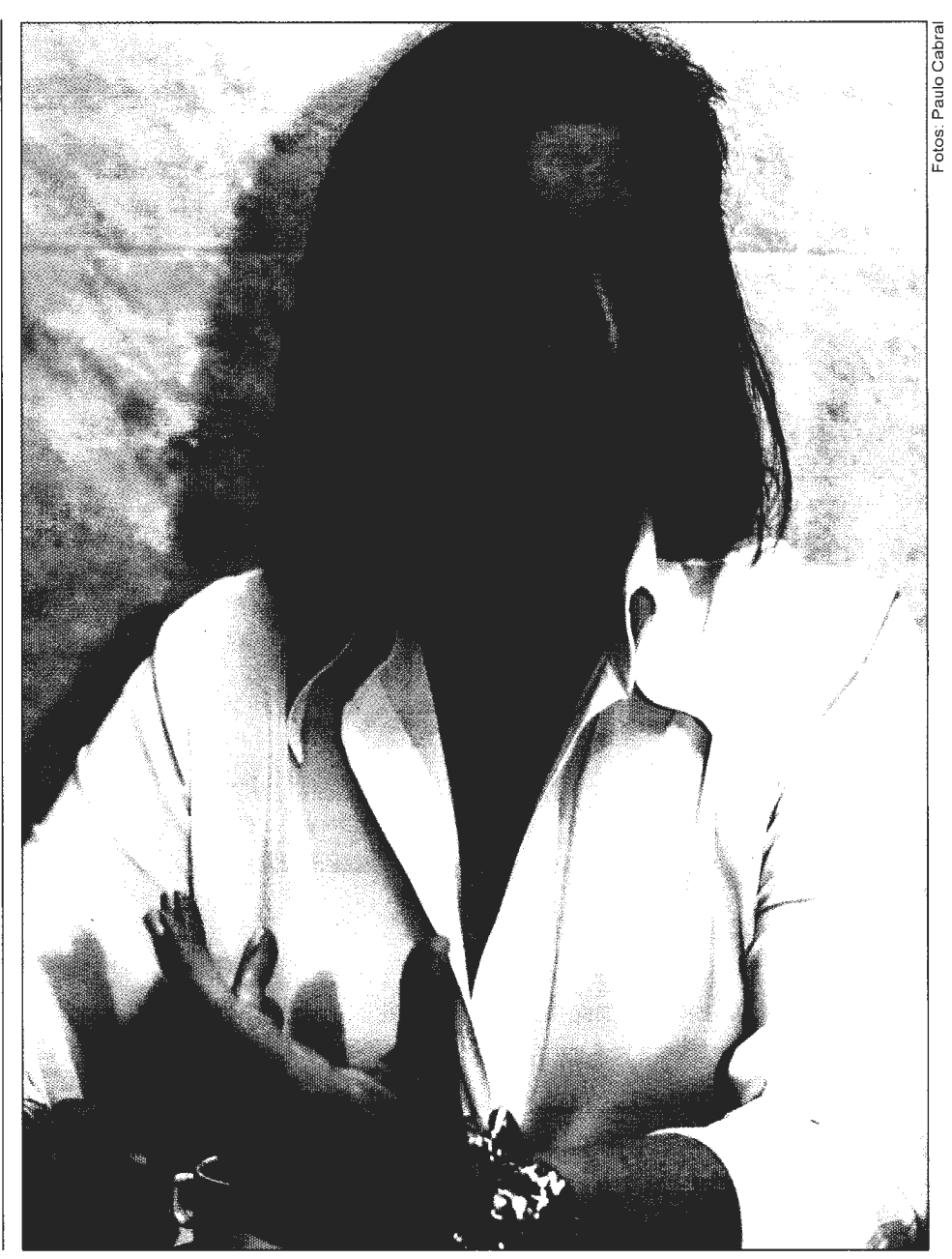


Nenhuma das outras cidades do país tem um centro tão bem localizado quanto o nosso: em pleno Eixo Monumental, ao lado da rede hoteleira. E como Brasilia é a capital do país, centro de todas as decisões nacionais, se um grande executivo de uma grande empresa estrangeira vier aqui para um congresso, por exemplo, e quiser falar com o presidente da República, com um dos ministros ou outra autoridade, terá mais facilidade.

$\boldsymbol{R F}$ : Houve um problema com relação à verba para a reforma do Centro de Convençñes de Brasília. Como está o andamento das obras e qual a garantia de que o empreendimento terá sua continuidade e prazos respeitados para aquelas empresas interessadas em investir na cidade?

LFL: O problema já foi resolvido. A garantia da continuidade da reforma do Centro de Convenções é a palavia do governador Joaquim Roriz e ele irá cumprila. Essa também é a minha garantia. A obra deve durar um ano e dois meses e a previsão para o funcionamento do Centro de Convenções é de um ano e meio.

$\boldsymbol{R F}:$ A senhora tem viajado muito participando de encontros e congressos da área, divulgando os projetos da Secretaria. Como esses projetos estão sendo recebidos nos outros estados?

LFL: Os projetos de turismo para Brasília, em geral, têm sido recebidos com grande entusiasmo e até com surpresa, pois Brasília não era muito ativa na área de Turismo. Dessa forma, quando as pessoas vêem a Secretaria de Turismo de Brasília atuando, participando, divulgando seus projetos, ficam muito entusiasmadas. E é impressionante o número de pessoas que não conhece Brasília. Jornalistas importantes de Curitiba nunca vieram a Brasília. Pessoas de Belo Horizonte Brasília é filha de Belo Horizonte -, da minha própria família não conhecem Brasília. Acho isso o absurdo dos absurdos, porque Brasília é a capital de todos os brasileiros. Aqui está uma parte importantíssima da nossa história. A cidade foi criada por um mineiro - o maior homem público que o Brasil já teve. Estava



ainda há pouco vendo um vídeo sobre a criação de Brasília que me emocionou. Se um brasileiro tem a coragem de construir a capital do Brasil em três anos e meio, nós temos que fazer grandes coisas nesses três anos e meio do governo Roriz, não é verdade? Agora, por exemplo, chegou o

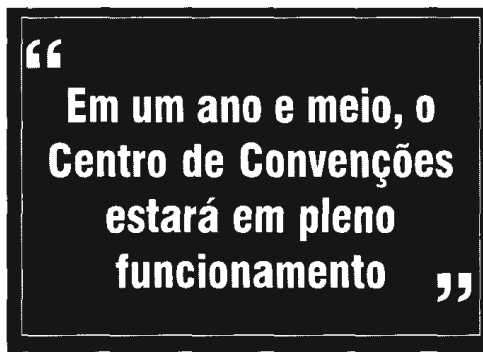

momento do Turismo, área que está sendo muito enfatizada, tanto pelo presidente da República, como pelo ministro Mares Guia, mas, sobretudo, pelo governador Roriz, porque ele está dando prioridade absoluta ao Centro de Convenções; está criando vários parques nas regiões do Entorno, que constituem pólos de atração turística. Estamos cuidando do Turismo Místico, muito importante para essa área do Brasil Central. Estamos estudando o Turismo Cívico-Cultural, ao qual chamaremos de aula aberta, trazendo alunos do ensino médio de todo o Brasil para que venham aqui com seus professores conhecer como funciona a capital do país. Assim, poderão orgulhar-se da capital federal e saber que é uma cidade onde todos trabalham para $o$ bem do Brasil.

RF: A Secretaria está dando enfoque ao Turismo Auto-Sustentável...

LFL: O Turismo Auto-Sustentável é aquele que se mantém, sem que o governo precise sustentá-lo. Claro que é preciso haver publicidade para estimular o turismo. O Brasil é um país muitíssimo abençoado, e Brasília, além de sua beleza arquitetônica, é uma cidade planejada que deu certo. Mas ainda é muito desconhecida pelos brasileiros e estrangeiros. E por quê? Por falta de promoção.

RF: A senhora não acha que as noticias negativas sobre Brasilia contribuem para criar preconceito nas pessoas em relação à cidade?

LFL: Acho que não. Se fosse assim, o mesmo aconteceria com Washington (EUA), Londres, em cidades do mundo inteiro, porque em todas as cidades há escândalos, não é verdade? Os escândalos de Brasília, quando acontecem, são importados, uma vez que se trata de pessoas que vêm de fora para exercerem seus mandatos aqui. Realmente eu não acredito nisto. Acho que Brasília é uma cidade muito importante, sedimentada e voltada para homens de negócio, de cultura e obviamente para quem procura o poder. 
RF: Quem são os parceiros da Secretaria hoje?

LFL: Temos parcerias com todas as secretarias do Distrito Federal, pela simples razão de que não há turismo sem parceria. As áreas de Saúde, Transporte, Desenvolvimento Urbano, Desenvolvimento Econômico e Cultura, todas são necessárias ao apoio do turista.

RF: O Senac ministra vários cursos na área de Hospitalidade e Turismo e conta com hotéis-escola no Brasil. Há alguma idéia de viabilizar parceria com esta entidade?

LFL: Claro que sim. Precisamos muito da parceria do Senac, e há a idéia do governo, da Secretaria, de fazer em Brasília uma escola de hotelaria. Esta escola de hotelaria poderá ser ao mesmo tempo um hotel para receber os hóspedes oficiais do governo. O governo está sempre recebendo visitas $e$, muitas vezes, não tem onde hospedá-las. Se existir uma escola de hotelaria, poderemos usá-la também como hotel. É uma idéia excelente. Já até pensei em um lugar, mas ainda não falei isso com o dono. Trata-se do Brasília Palace Hotel, que pertence ao senador Paulo Octávio. Seria uma ótima idéia se pudesse ser feito lá.

RF: Quais são os planos para o turismo Mistico e o Agroturismo?

LFL: A idéia do turismo Místico é em parceria com todos, principalmente, com os quatro estados do Brasil Central: Goiás, Tocantins, Mato Grosso e Mato Grosso do Sul. Faríamos um roteiro de turismo Místico, abrangendo estes estados, aproveitando o espiritualismo tão em moda. Hoje as pessoas estão mais em busca de espiritualização, de reencontro, de esperança. Em relação ao turismo Rural, esta área foi uma das que mais se desenvolveram no Distrito Federal nos últimos dois anos. O número de hotéisfazenda aumentou muito. O clima do hotelfazenda é muito agradável e é um programa bom para todas as idades. Se você quer sair com sua família, no meu caso, com os meus netos também, a praia já não é um programa para todos. Agora, se você vai para um hotel-fazenda, é uma delícia.

RF: Em relação ao artesanato, há um projeto voltado também para a revitalização da Torre de Televisão, incluindo a reorganização da Feira de Artesanato...

LFL: O artesanato é a paixão da minha vida. Ele demonstra a alma do povo, revelando sua gente. E como o Brasil é um país riquíssimo, com toda essa nossa miscelânea de raças, o resultado é fantástico. É a maneira que as pessoas têm de se expressarem, por meio da música, da comida e, sobretudo, do artesanato. Temos, portanto, muitos planos para o

\section{6 \\ Precisamos oferecer atividades culturais \\ e comércio ativo ao turista que nos visita

क日

artesanato e contamos com uma parceria com o Sebrae.

RF: A senhora tem uma identidade forte com Brasilia...

LFL: Tenho uma identidade inacreditável com Brasília. Conheci JK, quando meu marido trabalhou com ele como oficial de gabinete. Então, quando me casei, Brasília estava sendo construída, e, antes disso, eu já ouvia os sonhos sobre Brasília, as coisas que o presidente Juscelino queria fazer aqui nesta cidade. Em 1960, mudamos para Brasília com o governo, mas não ficamos aqui muito tempo, porque o embaixador Sérgio Câmara foi convidado para ser governador provisório do Rio de Janeiro e meu marido foi chefiar a Casa Civil. Mas em 1970, nós voltamos para Brasília e aqui ficamos até 1990. Quer dizer, meus filhos foram criados aqui. Espero que os mineiros não se aborreçam comigo, mas é a cidade em que passei a maior parte da minha vida. De Belo Horizonte, saí quando ia fazer 18 anos.
Em Brasília, somando tudo, já estou há 22 anos.

RF: Como a experiência da vida diplomática está contribuindo em seu trabalho à frente da Secretaria?

LFL: Muito mais do que eu imaginava. A gente vai vivendo, absorvendo conhecimentos quase sem perceber. Quando realmente fui lidar com o Turismo, uma área na qual formalmente eu não tinha experiência, fiquei surpresa de ver como todo esse longo percurso da minha vida havia sido importante. Fui turista, recebi turista a minha vida inteira, morei em cidades onde via turistas chegarem. Quer dizer, você acaba aprendendo o que o turista quer, o de que ele precisa, qual a melhor maneira de receber o turista em nossa cidade. Então foi muito interessante. Às vezes, até brinco com a equipe, todos profissionais da área. Digo para eles: respeitem minha quilometragem.

RF: O comércio no DF não funciona nos domingos e feriados. A senhora acredita que à medida que o turismo for incrementado este quadro irá mudar?

LFL: O mais necessário é incrementar o turismo de finais de semana para movimentar a rede hoteleira. Então o que é preciso trazer para esse tipo de turista? Atividades culturais e comércio ativo, pois o turista gosta de comprar e isso traz dinheiro para a cidade. Se eles chegam na sextafeira e no sábado, e a maioria do comércio fecha ao meio-dia ou às duas horas da tarde... Hoje já acho que sábado à tarde o comércio deveria estar aberto, não só pelos turistas, mas pelos habitantes do Distrito Federal. Quem trabalha a semana inteira, às vezes no sábado, de tarde quer ir a algumas lojas e elas estão fechadas. Isso tem me acontecido. Trata-se de uma necessidade da população. O turismo é feito para atender não só ao turista, mas também à população local, porque tudo o que melhora para o turista reverte em benefício da população local. 


\section{REFERÊNCIAS BIBLIOGRÁFICAS}

ANJOS, RSA. Cartografia e dinâmica territorial - projeto de popularização da Informação Geográfica. Anais do XX Congresso Brasileiro de Cartografia. Porto Alegre, 2001.

ANDRADE, Jose Vicente de. Turismo, Fundamentos e Dimensões. Ed. Ática,São Paulo, 1998.

ANSARA, Marilia Gomes dos Reis (org). Turismo: Como Aprender, Como Ensinar - vol. 1. Ed. Senac. São Paulo, 2ª ed. 2001.

ANSARA, Marilia Gomes dos Reis (org). Turismo: Como Aprender, Como Ensinar - vol. 2. Ed. Senac. São Paulo, 2ª ed. 2001.

CRUZ, Rita de Cássia Ariza da. Política de Turismo e Território. Ed. Contexto, São Paulo, 2002.

CRUZ, Rita de Cássia. Introdução à geografia do turismo. Ed. Roca, São Paulo, 2001.

FREIRE, Paulo. A Importância do Ato de Ler. Cortez Editora, São Paulo, 1991.

FREIRE, Paulo. Pedagogia da Autonomia. $25^{\mathrm{a}}$ ed. Ed. Paz e Terra, São Paulo, 1996.

FREYRE, Gilberto. Brasil, Brasis e Brasília. Ed. Livros do Brasil Lisboa, Lisboa.

HALL, C. Michael. Planejamento Turístico - Políticas, Processos e Relacionamentos. Ed. Contexto, São Paulo, 2001.

IGNARRA, Luiz Renato. Fundamentos do Turismo. Ed. Pioneira, São Paulo, 1999. 
LASSANCE, Adalberto, et. Alli. Brasília: a Capital do Brasil. Ed. Porfiro, Brasília, 2003.

LICKORISH, Leonard J. e JENKINS, Carson L. Introdução ao Turismo. Ed. Campus, $2^{\mathrm{a}}$ ed. 2000.

NEVES, Ézia S. Paisagem - Conceitos in: Paisagem e Ambiente - Ensaios IV, 1992.

PENIN, Sonia P. de Sousa. A Aula: Espaço de Conhecimento, Lugar de Cultura. Ed. Papirus, 1994.

PUTTEVILS, Charles J. L. Contribuição ao melhoramento de plantas urbanas de orientação. Análise comparativa entre plantas brasileira e do exterior. Dissertação de mestrado. UNB, Brasília, 2002

ROJOWSKI, Miriam. Turismo como Disciplina no Pensamento Internacional. $3^{\mathrm{a}}$ ed. Papirus Editora,1994.

SANTOS, Milton. O Retorno do território.Território, Globalização e fragmentação. Ed Hucitec, 1998.

SEDF. Currículo da Educação Básica das Escolas Públicas do Distrito Federal. Brasília, 2001.

SEDF. Parâmetros Curriculares Nacionais - Introdução. MEC-SEF, Brasília, 1998.

SENAC. Introdução ao Turismo e Hotelaria. Rio de Janeiro, Ed. Senac, 1998.

VELOSO, Marcelo Parreira, Turismo Simples e Eficiente. São Paulo, ed. Roca, 2003.

WETTSTEIN, German. Subdesenvolvimento e geografia. Ed. Contexto, São Paulo, 1997.

Congresso Brasileiro de Docência e Pesquisa em Turismo, 1‥ Campo Largo, PR, 2002. 
COOPER, Cris et.Alli. Turismo, Princípios e Práticas. $2^{\mathrm{a}}$ ed. Porto Alegre, Ed. Bookman, 2001.

ROLNIK, Raquel. O Que é Cidade. Ed. Brasiliense, 2ª ed. são Paulo , 1998.

TRIGO, Luiz Gonzaga Godoi. Turismo Básico. 6ª ed. Ed. Senac, São Paulo, 2002.

BECKER, Bertha K, Ciência Hoje no 117 vol. 20. Referência retirada do site: http//www.agbcuritiba.hpg.ig.com.br/textos/bertha.htm

ROJOWSKI, Miriam. Turismo e Pesquisa Científica. Ed. Papirus, 1996

EMBRATUR. GUIA TURISTICO DE BRASILIA. Ed. Imagem, Brasília, 2001.

EMBRATUR. Guia Turístico de Brasília. Ed. Imagens, 2001

MINISTÉRIO DO TURISMO. Plano Nacional do Turismo. Brasília, 2003.

CORREIO BRASILIENSE, Caderno Cidades, 21 de setembro de 2003.

REVISTA FECOMÉRCIO. Brasília, nº 78. maio, 2003.

SITE: www.brasiliense.hpg.ig.com.br

SITE: www.Viaecológica.com.br

SITE: www.prometeus.itsa.com.br

SITE: www.secturbc.com.br

SITE: www.brasiliaconvencion.com.br 